\title{
Foraging habitat of North Atlantic right whales has declined in the Gulf of St. Lawrence, Canada, and may be insufficient for successful reproduction
}

\author{
Katherine Gavrilchuk ${ }^{1, *}$, Véronique Lesage1, ${ }^{1}$ Sarah M. E. Fortune ${ }^{2}$, \\ Andrew W. Trites ${ }^{2}$, Stéphane Plourde ${ }^{1}$ \\ ${ }^{1}$ Fisheries and Oceans Canada, Mont-Joli, QC G5H 3Z4, Canada \\ ${ }^{2}$ Marine Mammal Research Unit, Institute for the Oceans and Fisheries, University of British Columbia, Vancouver, \\ BC V6T 1Z4, Canada
}

\begin{abstract}
Climate-induced changes in calanoid copepod (Calanus spp.) availability in traditional feeding areas might explain why a large proportion of the North Atlantic right whale Eubalaena glacialis population has fed in the Gulf of St. Lawrence (Canada) in recent years. However, little is known about the distribution of copepods in the gulf, and whether their abundance is sufficient to energetically sustain right whales. We used a mechanistic modelling approach to predict areas within the gulf that have foraging potential for adult female right whales, based on the annual energetic needs of resting, pregnant and lactating females, and their theoretical prey density requirements. We identified suitable foraging areas for right whales by coupling a foraging bioenergetics model with a 12 yr data set (2006-2017) describing the abundance and 3-dimensional distribution of late-stage Calanus spp. in the gulf. Prey densities in the southern gulf (from Shediac Valley to the Magdalen Islands) supported all 3 reproductive states in most $(\geq 6)$ years. However, foraging habitat became progressively sparse in the southern gulf over time, with noticeably less suitable habitat available after 2014. Few other potentially suitable foraging areas were identified elsewhere in the gulf. Overall, the availability of foraging habitat in the gulf varied considerably between years, and was higher for resting females than for pregnant and lactating females. Our findings are consistent with the recent low calving rates, and indicate that prey biomass in the Gulf of St. Lawrence may be insufficient in most years to support successful reproduction of North Atlantic right whales.
\end{abstract}

KEY WORDS: Eubalaena glacialis $\cdot$ Habitat suitability $\cdot$ Foraging $\cdot$ Bioenergetics $\cdot$ Calanus spp. Gulf of St. Lawrence · North Atlantic right whale

\section{INTRODUCTION}

A central objective of applied biological conservation is to identify and control potential threats in important geographic areas used by vulnerable species. Important areas for vulnerable species (or populations) can be identified using correlative or mechanistic modelling approaches (Kearney et al. 2010). Correlative modelling approaches attempt to link species occurrence with simultaneously collected

*Corresponding author: katy.gavrilchuk@gmail.com environmental variables and predict species distribution using associated spatial correlates (Guisan \& Zimmermann 2000). In contrast, mechanistic or bottom-up modelling approaches evaluate the biophysiological traits of a species to determine which habitat conditions likely favour species occurrence or fitness (Kearney \& Porter 2009). Mechanistic habitat modelling seeks to understand the latent processes responsible for animal use of a given area, and is often rooted in first principles of physiology and biome-

() The authors 2021. Open Access under Creative Commons by Attribution Licence. Use, distribution and reproduction are unrestricted. Authors and original publication must be credited. 
chanics, which govern all organisms (Peterson et al. 2015). The fundamental unit of measure in such models is energy (expressed in J), known as the universal currency in ecology for its direct influence on survival and reproduction (Stephens \& Krebs 1986, MacNab 2002).

Bioenergetic habitat suitability models are mechanistic in nature, incorporating physiological traits and energy requirements of organisms to better understand patterns of habitat use (van der Vaart et al. 2016). Such models are a valuable tool in wildlife research and management, and have been used to identify suitable habitat for a variety of species globally (e.g. Tomlinson et al. 2014, Silber et al. 2017). Understanding the energy requirements of a species can further help predict future distributions, and evaluate the energetic costs associated with anthropogenic disturbance that reduce foraging success and ultimately impede population growth or recovery (Costa 2012).

From a reductionist perspective, the likelihood of an animal feeding at a given location reflects the trade-off between energy expended and energy gained, where animals are assumed to favour food items or foraging sites that provide a gain in net energy over the long term, needed to sustain life history functions and vital rates (Hall et al. 1992, Olsson \& Bolin 2014). In general, energy intake depends on body size, physiological requirements, nutritional status and the environmental factors influencing the spatial distribution, availability, quantity and quality of food sources (Chipps \& Wahl 2008). In turn, energy expenditure depends on physiological requirements such as basal maintenance, growth, gestation, lactation, thermoregulation, digestion and locomotion (Sibly \& Calow 1986). Consequently, a particular habitat may not be equally suitable for all demographic groups of a population. Bioenergetic models can therefore be generated with special focus on susceptible demographic groups, such as reproductively mature females that have higher energetic burdens and play a critical role in supporting newborn survival (Fortune et al. 2013, New et al. 2013, VillegasAmtmann et al. 2015).

The North Atlantic right whale Eubalaena glacialis (hereafter right whale) is a Critically Endangered balaenid cetacean (Cooke 2020), distributed primarily in coastal waters of the western North Atlantic, from the southeastern USA to eastern Canada (COSEWIC 2013). The population numbered between 444 and 471 individuals in 2015 (Pace et al. 2017), but has since declined due to a combination of low calving rates and high mortality rates (Pettis et al. 2018, 2020). Mortality caused by fishing gear entanglement and vessel strikes has been the primary driver of population decline (Corkeron et al. 2018, Sharp et al. 2019). A portion of the right whale population, comprised mostly of reproductively mature females, calves and some juveniles, migrates annually between winter calving areas off Georgia and Florida (USA) and summer feeding areas in the northern USA and Canada (Gowan et al. 2019). Since the early 1980s, around two-thirds of the population occupied the lower Bay of Fundy and the Scotian Shelf during summer and fall. Small numbers of animals also fed in the Gulf of St. Lawrence (COSEWIC 2013; Fig. 1). However, seasonal occurrence patterns have noticeably shifted during the last decade, with long-term acoustic detections indicating that right whales occur less frequently in the Bay of Fundy and the greater Gulf of Maine, and more frequently in southern New England and the mid-Atlantic region year-round (Davis et al. 2017). This change in distribution is also supported by long-term sightings data that report significantly fewer right whales on traditional, highuse feeding grounds such as the Bay of Fundy over the past decade (Davies et al. 2019). Passive acoustic monitoring has also detected an increase in summertime use of the Gulf of St. Lawrence by right whales since at least 2015 (Simard et al. 2019).

The shift in distribution of right whales away from their traditional feeding grounds may reflect a climate-induced change in the distribution and availability of prey (Meyer-Gutbrod et al. 2015, Record et al. 2019). Warming ocean temperatures may continue to move right whales further north given the northward range shifts observed in some forage species, and the impact that warmer waters throughout the Northeast US Shelf are predicted to have on the distribution and abundance of zooplankton (Reygondeau \& Beaugrand 2011, Grieve et al. 2017). Such changes in prey availability may also result in some right whales forgoing migration to wintering grounds off the southeastern USA in years of reduced prey availability (Krzystan et al. 2018, Gowan et al. 2019).

Larger-sized calanoid copepods such as Calanus finmarchicus, C. glacialis and C. hyperboreus dominate the total mesozooplankton biomass in the western North Atlantic (Pepin et al. 2015). Right whales have been observed to primarily forage on calanoid copepods such as late-stage C. finmarchicus, Pseudocalanus spp. and Centropages spp. (reviewed by Baumgartner \& Mate 2003) and occasionally on euphausiids (see Murison \& Gaskin 1989). However, right whale baleen is most efficient at filtering the larger, late-stage (CIV to adult) copepods (Mayo et al. 2001). Given the strong correlation between 


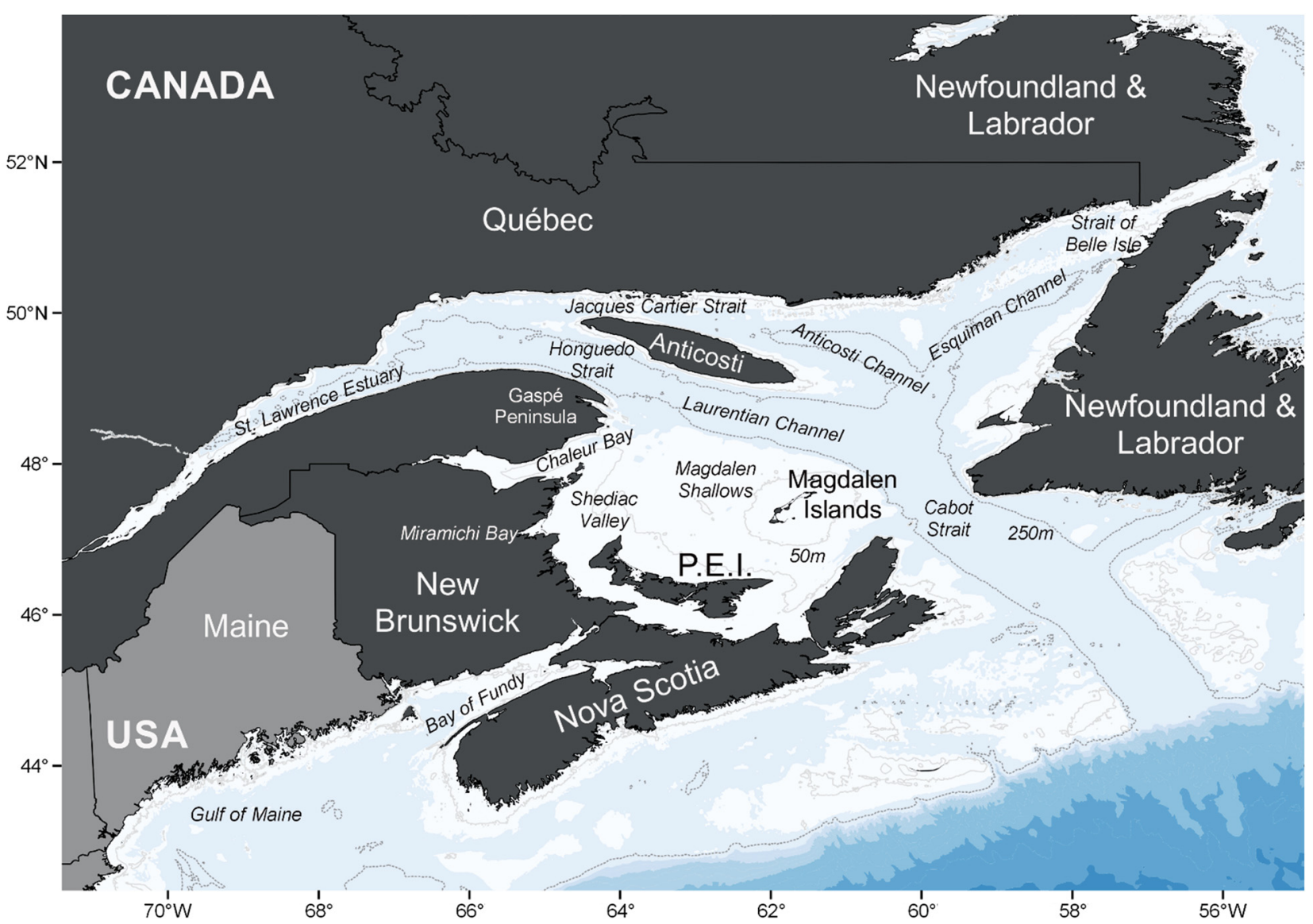

Fig. 1. Estuary and Gulf of St. Lawrence, Canada, P.E.I.: Prince Edward Island

C. finmarchicus abundance in the Gulf of Maine and right whale body condition and calving rates (reviewed by Meyer-Gutbrod \& Greene 2018), it is reasonable to suspect that shifts in right whale distribution during the feeding season reflect changes in the availability and/or distribution of C. finmarchicus. Predicting which new geographical areas may attract right whales based on their energetic requirements and the distribution of their preferred prey is one means to inform future monitoring efforts and conservation of this Critically Endangered species.

A preceding study evaluated areas of suitable foraging habitat for right whales in the Gulf of St. Lawrence, Scotian Shelf and Bay of Fundy by applying basic energy requirements of an average right whale to a 3-dimensional (3D) spatial climatology of multi-year average Calanus spp. densities (Plourde et al. 2019). Here, we built on the work of Plourde et al. (2019) by assessing interannual variation in the 3D Calanus spp. prey field and increasing the resolution of the bioenergetics model. We also predicted the energy requirements of reproductively mature adult females in order to assess the suitability of the Gulf of St. Lawrence to meet their foraging needs. This study supports future survey planning and identification of areas that may benefit from adaptive management approaches to protect right whales from human-caused mortality in eastern Canadian waters.

\section{MATERIALS AND METHODS}

\subsection{Data collection}

Zooplankton sampling surveys conducted in the Estuary and Gulf of St. Lawrence since 1979 have yielded a prey database with broad spatial and temporal coverage (Plourde et al. 2019). The term Gulf of St. Lawrence or gulf will refer to both the Estuary and Gulf regions combined from here on. For our study, we selected sampling years with the most consistent spatial coverage (2006 to 2017) during the summer period (June to September), a period that coincides with the peak abundance of right whales in this area (DFO 2019a). Early summer surveys (June to early July) were primarily carried out in the south- 
ern gulf following a systematic design, while the late summer surveys (late July to September) covered mainly the northern gulf and followed a random sampling design (Fig. 2). Sampling surveys were conducted in the absence of foraging right whales.

The methodology for depth-integrated zooplankton sampling and abundance assessment (ind. $\mathrm{m}^{-2}$ ) for the 3 dominant Calanus copepod species (C. finmarchicus, C. glacialis and C. hyperboreus) was summarized by Plourde et al. (2019) and Sorochan et al. (2019). Briefly, samples were collected with oblique or vertical tows respectively performed with Bongo nets (opening $0.61 \mathrm{~m}$; mesh size $333 \mu \mathrm{m}$ ) or ring nets (opening $0.75 \mathrm{~m}$; mesh size $200 \mu \mathrm{m}$ ). Samples were analysed using a semi-automated image analysis procedure for species and life-stage identification and enumeration, resulting in 2 copepod classes that encompassed multiple copepodite stages: $C$. finmarchicus and C. glacialis CIV-VI, and C. hyperboreus CIV-VI. These copepod classes overwhelmingly dominated the size fraction $>1 \mathrm{~mm}$, and were considered a good proxy of Calanus spp. biomass. The semi-automated estimates of in situ Calanus spp. abundance were then corrected based on the relationship between taxonomist-measured abundance and semi-automated analysis in a subset of samples
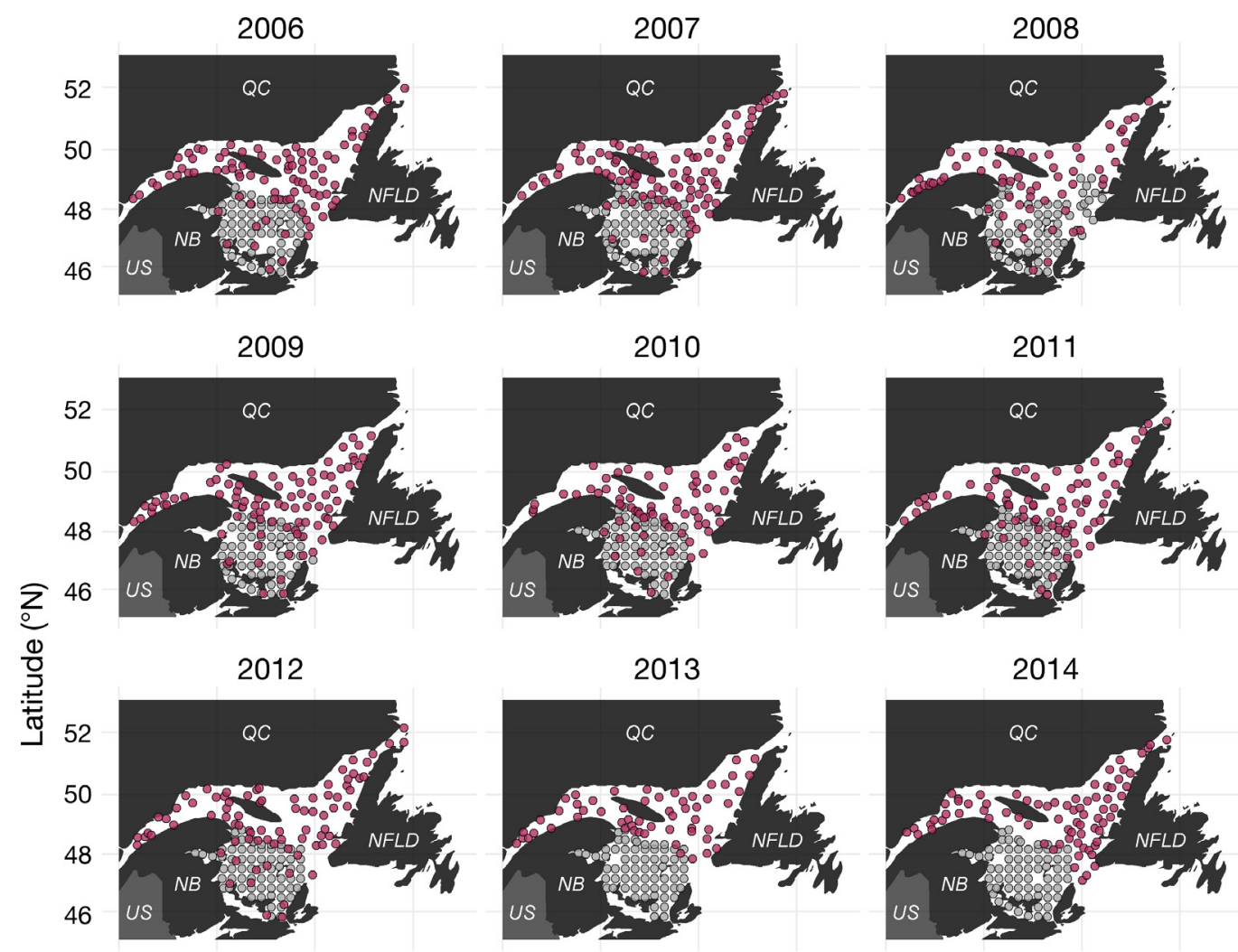

2013
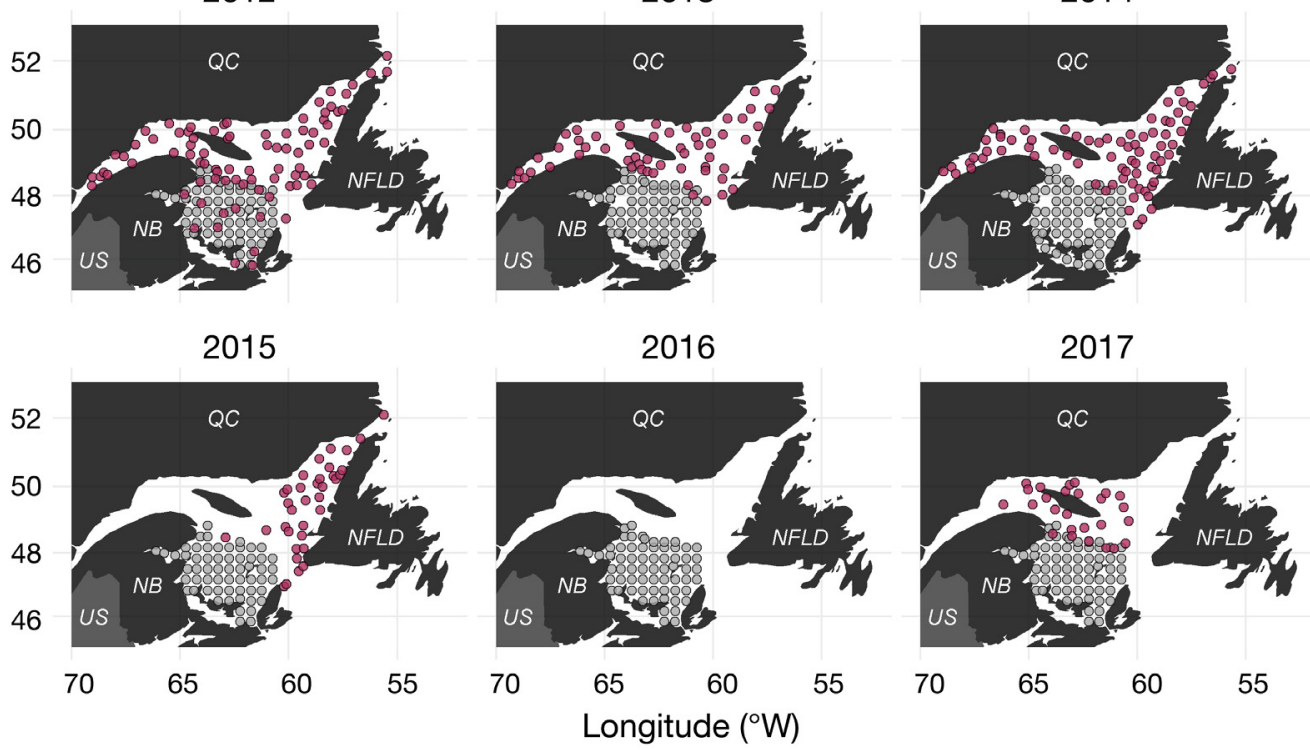

Fig. 2. Calanus spp. sampling stations in the Estuary and Gulf of St. Lawrence, Canada, from 2006 to 2017 . Early summer sampling (June to early July) occurred in the southern Gulf of St. Lawrence (grey points), and late summer sampling (late July to September) occurred primarily in the northern Gulf of St. Lawrence (pink points). Note that in 2016, only early summer data were available. NFLD: Newfoundland and Labrador, QC: Quebec, NB: New Brunswick, US: USA (Maine) 
(see Plourde et al. 2019 for further details). For this modelling exercise, we assumed that right whales forage on all 3 Calanus species, particularly on the later development stages (CIV-VI), which is consistent with knowledge of their foraging ecology. We grouped these stages and species to obtain a total Calanus species biomass measurement for each sampling station in the Gulf of St. Lawrence following Plourde et al. (2019).

\subsection{Prey field}

Following the steps described in Table 1, we generated a continuous prey field over the study area based on depth-integrated Calanus spp. dry weight

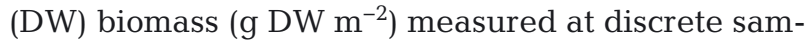
pling stations in the Gulf of St. Lawrence over the 12 yr study period (2006-2017). We first used Bayesian geostatistical inference to predict the 2-dimensional (2D), depth-integrated prey field for both early and late summer of each year (e.g. Cosandey-Godin et al. 2015). We included potential static (bathymetry and slope) and dynamic (sea surface temperature, SST) environmental correlates known to affect zooplankton abundance to explore their utility in informing Calanus spp. biomass predictions (AlbouyBoyer et al. 2016, Plourde et al. 2016). Bathymetry (or depth, $\mathrm{m}$ ) and slope $\left(^{\circ}\right)$ data for each sampling station was obtained from the satellite-derived, high-resolution (1 $\mathrm{km}^{2}$ grid) MARSPEC database (www.marspec. org). Daily SST data were extracted via the ERDDAP data server from the Multi-scale Ultra-high Resolution $\left(1 \mathrm{~km}^{2}\right.$ ) SST Global database (NASA JPL) (originally downloaded from https://coastwatch.pfeg.noaa.gov/ erddap/griddap/jplMURSST.html). We used continuous domain stochastic partial differential equations to solve the covariance spatial structure of Calanus spp. biomass measurements (Lindgren et al. 2011) using the R package R-INLA (www.r-inla.org). Given that our response variable (Calanus spp. biomass) was positive-continuous with a small percentage $(1 \%)$ of zeros, to avoid removing the zero data, we added a negligibly small value $(0.001)$ to the zeros and evaluated the goodness of fit of 3 candidate distributions (gamma, exponential and lognormal).

The relationship between Calanus spp. biomass measurements and environmental correlates was modelled separately for each year, and for early summer (June to early July) and late summer (late July to September) (Eq. 1). The best-performing model (based on goodness of fit and predictive performance) was then used to predict Calanus spp. biomass at unsampled locations in our study area. To begin, we let $y(s)$ denote the realisation (i.e. one set of possible outcomes) of a stochastic spatial process $Y(s)$, which corresponds to our Calanus spp. biomass measurements $\left(y_{1}, \ldots, y_{N}\right)$ sampled at locations $s_{1}, \ldots, s_{N}$, such that:

$$
y\left(s_{i}\right)=z\left(s_{i}\right) \beta+w\left(s_{i}\right) \varepsilon\left(s_{i}\right)
$$

where location $S$ is a spatial index of latitudelongitude values, $z\left(s_{i}\right)$ is a vector of covariate values for location $s_{i}$, and $\beta$ is a vector of regression coefficients. The $w\left(s_{i}\right)$ are the spatially correlated random effects, which capture any spatial pseudoreplication in the data, and are represented by a Gaussian Markov random field with mean 0 and covariance matrix $\Sigma$ where the Matérn correlation function is used to parameterise the covariance matrix. The $\varepsilon\left(S_{i}\right)$ are the independently distributed, spatially uncorrelated regression residuals where $\varepsilon\left(S_{i}\right) \sim N\left(0, \sigma_{\varepsilon}^{2}\right)$ (Lindgren et al. 2011, Cameletti et al. 2013). All covariates were included as smoothed (non-linear) effects given the non-linear relationships observed with the response variable during data exploration. All environmental correlates were standardized to avoid numerical esti-

Table 1. Methods used to assess the suitability of habitat for North Atlantic right whales summarized in 5 steps

\begin{tabular}{|lll}
\hline Step & Description & Approach \\
\hline 1 & $\begin{array}{l}\text { Render point sampling observations of Calanus spp. biomass into a } \\
\text { 2D continuous prey field, accounting for spatial autocorrelation }\end{array}$ & Bayesian hierarchical spatial model \\
2 & $\begin{array}{l}\text { Project continuous prey field onto a regular } 10 \mathrm{~km}^{2} \text { grid covering } \\
\text { study area }\end{array}$ & Bayesian hierarchical spatial model \\
3 & $\begin{array}{l}\text { Apply Calanus spp. vertical distribution model to transform prey field } \\
\text { from 2D to 3D }\end{array}$ & Generalized additive model \\
& $\begin{array}{l}\text { Apply right whale foraging bioenergetics model to transform 3D prey } \\
\text { field into a 3D net energy field } \\
\text { Convert net energy field into a foraging habitat suitability grid }\end{array}$ & $\begin{array}{l}\text { Theoretical time-activity budget } \\
\text { bioenergetics model } \\
\text { Summarize relative foraging value of }\end{array}$ \\
& & $\begin{array}{l}\text { each grid cell across space (study } \\
\text { area) and time (12 yr study period) }\end{array}$
\end{tabular}


mation issues and to facilitate interpretation of regression parameters.

Under the Bayesian paradigm, model parameters are considered random variables and defined using prior probability distributions. For the smoothed effect of the covariates, we assigned a first-order random walk model (Krainski et al. 2018) with penalized complexity (PC) prior probability distributions recommended by Simpson et al. (2017), where the probability of the covariates prior standard deviation $\left(\sigma_{\mathrm{c}}\right)$ being $>1$ is 0.05 . For the spatial random effect, we set PC priors for the spatial correlation range $r$ and $\sigma_{\mathrm{r}}$ so that $P(r<10)=0.05$ and the $P\left(\sigma_{\mathrm{r}}>3\right)=0.05$ (Fuglstad et al. 2019).

We compared various candidate models (all additive covariate combinations) fitted with and without the spatial random effect using the deviance information criterion (DIC, Spiegelhalter et al. 2002) and the Watanabe-Akaike information criterion (WAIC, Watanabe 2010), where lower DIC or WAIC values indicate higher goodness of fit. Two additional crossvalidation methods were used to assess predictive performance of candidate models. We first randomly selected $80 \%$ of the stations for model estimation and $20 \%$ for validation to evaluate how well the model predicted Calanus spp. biomass at validation stations based on the correlation between observed and predicted Calanus spp. biomass. We then used the builtin R-INLA leave-one-out cross-validation diagnostic (the conditional predictive ordinate, $\mathrm{CPO}$ ), which calculates a prediction error score for each observation. To summarize CPO values for all observations into 1 metric, we computed the sum of all log CPO values, for which larger values indicate better model predictive power (Gneiting \& Raftery 2007).

We then used the final model to predict depthintegrated Calanus spp. biomass on a $10 \times 10 \mathrm{~km}$ regular grid covering the study area in early summer (15 June) and late summer (15 August) for each study year. We extended our predictions to a maximum distance of $30 \mathrm{~km}$ from sampling sites to reduce uncertainty, and obtained covariate values at prediction locations the same way as for the observed Calanus spp. data.

Preceding studies assessed the seasonal vertical distribution of Calanus copepods in the western North Atlantic using depth-stratified abundance and biomass data, and a generalized additive modelling approach (Krumhansl et al. 2018, Plourde et al. 2019). One of their resulting models predicts the daily averaged relative proportion (\%) of depth-integrated total Calanus spp. biomass in $10 \mathrm{~m}$ depth intervals from surface to sea floor, capturing the seasonal changes in Calanus spp. vertical distribution associated with the transition between the active (0-100 $\mathrm{m}$; late spring and early summer) and diapausing $(>100 \mathrm{~m}$; late summer) phases of their life cycle (Plourde et al. 2019). This model adequately described the concentrating effect on Calanus spp. biomass density $\left(\mathrm{g} \mathrm{m}^{-3}\right)$ in areas where the sea floor is shallower $(<100 \mathrm{~m})$ than the optimal overwintering depth $(>150 \mathrm{~m})$ selected by Calanus spp. in deep areas (Plourde et al. 2019). We therefore applied this Calanus spp. biomass relative (\%) vertical distribution model to our 2D $10 \mathrm{~km}^{2}$ grid of predicted depthintegrated Calanus spp. biomass $\left(\mathrm{g} \mathrm{m}^{-2}\right)$ to produce a $3 \mathrm{D}$ representation of the prey density $\left(\mathrm{g} \mathrm{m}^{-3}\right)$ field.

\subsection{Foraging bioenergetics model}

\subsubsection{Net energy field}

From the 3D prey field, we extracted 2 parameters for the foraging bioenergetics model described below: Calanus spp. biomass density $\left(\mathrm{g} \mathrm{m}^{-3}\right)$ predicted in $10 \mathrm{~m}$ depth bins, and the depth of each layer or transit distance from the water surface to access prey. We then applied the foraging bioenergetics model to the 3D prey field by evaluating the balance between energy gain and expenditure for a given prey biomass density in a particular $10 \mathrm{~m}$ depth bin. This produced a 3D net energy field, where each $10 \mathrm{~km}^{2}$ xyz location (latitude-longitude-depth) had a net energy index $\left(E_{\text {net }}\right)$ represented by the following simple theoretical energy balance (Eq. 2):

$$
E_{\text {net }}=\frac{E_{\text {in }}-E_{\text {out }}}{E_{\text {out }}}
$$

where $E_{\text {net }}$ is the proportion of energy gained $\left(E_{\text {in, }}\right.$ Eq. 3) or expended ( $E_{\text {out }}$ Eq. 4$)$, relative to energy expended $\left(E_{\text {out }}\right)$. An $E_{\text {net }}$ value of 0 signifies that energy gained equals energy expended. We considered $E_{\text {net }}=0$ to be the minimum theoretical foraging threshold. Any xyz locations with $E_{\text {net }}$ values $>0$ were defined as 'suitable' for meeting the daily energy requirements of right whales based on the foraging assumptions made below. Values for model parameters are summarized in Table 2.

\subsubsection{Energy gain}

Right whales feed by ram filtration, which involves passively filtering large volumes of prey-filled water by slowly swimming forward with their mouth open (Mayo \& Marx 1990). The volume of prey-water fil- 
Table 2. List of parameters used in the bioenergetics model for North Atlantic right whales

\begin{tabular}{|c|c|c|c|}
\hline Symbol & Parameter (unit) & Value(s) & Reference \\
\hline$\alpha$ & Skin friction coefficient constant & 0.072 & Phillips et al. (2017) \\
\hline$A$ & Total wetted surface area $\left(\mathrm{m}^{2}\right)$ & $0.08 \operatorname{mass}^{0.65}$ & Fish (1993) \\
\hline$A_{\mathrm{m}}$ & Mouth opening area $\left(\mathrm{m}^{2}\right)$ & $1.7,1.9$ & van der Hoop et al. (2019) \\
\hline$\beta$ & Skin friction coefficient exponent & -0.2 & Phillips et al. (2017) \\
\hline$d$ & Body diameter (m) & 3.15 & Nousek McGregor (2010) \\
\hline$D_{\mathrm{p}}$ & Prey density $\left(\mathrm{g} \mathrm{m}^{-3}\right)$ & & This study \\
\hline$E_{\mathrm{p}}$ & Prey energy content $\left(\mathrm{MJ} \mathrm{g}^{-1}\right)$ & $0.0229,0.0329$ & Davies et al. (2012) \\
\hline$\varepsilon_{\mathrm{A}}$ & Dietary assimilation efficiency & $0.80,0.92$ & Lockyer (1981), Swaim et al. (2009) \\
\hline$g$ & Appendage drag & 1.3 & Fish \& Rohr (1999), van der Hoop et al. (2014) \\
\hline$L$ & Body length (m) & 14 & Moore et al. (2005) \\
\hline Mass & Body mass (kg) & 35000 & Moore et al. (2005) \\
\hline Mass $_{\mathrm{nb}}$ & Newborn body mass (kg) & 790,1412 & Fortune et al. (2012) \\
\hline$\eta_{\mathrm{m}}$ & Muscular/metabolic efficiency & 0.25 & Kleiber (1961), Webb (1975) \\
\hline$\eta_{\mathrm{p}}$ & Propulsive/propeller efficiency & 0.51 & van der Hoop et al. (2017b) \\
\hline$t_{\mathrm{b}}$ & Bottom (ingestion) time (s) & $\begin{array}{l}\text { m: } 0.0704 \times \text { depth } \\
>150 \mathrm{~m}: 636\end{array}$ & Baumgartner et al. (2017), see Section 2 \\
\hline$t_{\mathrm{s}}$ & Post-dive surface time (s) & $\begin{array}{l}\text { g: } 0.211 \times \text { total time } \\
\text { h, Pregnant/lactating: } \\
\times \text { total time at depth }\end{array}$ & Baumgartner \& Mate (2003) \\
\hline$t_{\text {glide }}$ & Proportion of time spent gliding & $\begin{array}{l}\text { Irface/travel: } 0.09 \\
\text { Ascent: } 0.30 \\
\text { Descent: } 0.36 \\
\text { Bottom: } 0.09\end{array}$ & $\begin{array}{l}\text { Nowacek et al. (2001), } \\
\text { Nousek-McGregor (2010), } \\
\text { Nousek-McGregor et al. (2014) }\end{array}$ \\
\hline$U_{\mathrm{b}}$ & Foraging swim speed $\left(\mathrm{m} \mathrm{s}^{-1}\right)$ & 1.0 & $\begin{array}{l}\text { Baumgartner \& Mate (2003), } \\
\text { Nousek-McGregor (2010) }\end{array}$ \\
\hline$U_{\mathrm{a},} U_{\mathrm{d}}$ & Ascent, descent swim speed $\left(\mathrm{m} \mathrm{s}^{-1}\right)$ & 1.45 & Baumgartner et al. (2017) \\
\hline$U_{\mathrm{t}}$ & Travel swim speed $\left(\mathrm{m} \mathrm{s}^{-1}\right)$ & 2.0 & Goodyear (1996) \\
\hline$V$ & Kinematic viscosity of seawater $\left(\mathrm{m}^{2} \mathrm{~s}^{-1}\right)$ & $1.83 \times 10^{-6}$ & Kaye \& Laby (1995) \\
\hline$\gamma$ & Surface wave drag & 1.0 & See Section 2 \\
\hline$\rho$ & Density of seawater $\left(\mathrm{kg} \mathrm{m}^{-3}\right)$ & 1028 & Miller et al. (2016) \\
\hline$\lambda$ & Active-to-passive drag ratio & 1.0 & See Section 2 \\
\hline$\theta$ & Body angle during dive $\left({ }^{\circ}\right)$ & ent: 62 , descent: 74 & Nousek-McGregor et al. (2014) \\
\hline
\end{tabular}

tered per unit time can be used to approximate the rate of energy gain $\left(E_{\text {in }}\right)$ in $\mathrm{MJ} \mathrm{d}^{-1}$ (Baumgartner \& Mate 2003):

$$
E_{\text {in }}=\left(A_{\mathrm{m}} U_{\mathrm{b}} T_{\mathrm{b}} E_{\mathrm{p}} D_{\mathrm{p}}\right) \varepsilon_{\mathrm{A}}
$$

which depends on mouth opening area $\left(A_{\mathrm{m}}, \mathrm{m}^{2}\right)$, swim speed during feeding $\left(U_{\mathrm{b}}, \mathrm{m} \mathrm{s}^{-1}\right)$, time spent ingesting prey $\left(T_{\mathrm{b}}, \mathrm{s} \mathrm{d}^{-1}\right)$, prey energy content $\left(E_{\mathrm{p}}, \mathrm{MJ}\right.$ $\left.\mathrm{g}^{-1}\right)$, prey density $\left(D_{\mathrm{p}}, \mathrm{g} \mathrm{m}^{-3}\right)$ and dietary assimilation efficiency $\left(\varepsilon_{\mathrm{A}}\right)$, or the ratio of energy gained to energy ingested after digestion (Table 2, see Text S1 in the Supplement at www.int-res.com/articles/suppl/n044 p113_supp.pdf for justification of parameter values).

\subsubsection{Energy expenditure}

We evaluated the annual 'cost of living' for an adult female North Atlantic right whale in either a resting (i.e. reproductively mature but not pregnant or lactating), pregnant or lactating state that forages during the summer, breeds or calves in the winter and migrates during the fall and spring. Using available literature on the general activity budget of North Atlantic right whales (Table 3, and references therein), we created a time-activity budget in which the proportion of time a right whale spends in 3 principal activity states (foraging, resting and travelling/ socializing) varied with season. Foraging was set as the main activity during the summer and was considered negligible during migration and while on the wintering grounds. Travelling was set as the main activity during the fall and spring migrations, and travelling and/or socializing as the main activities during winter (Table 3). Given the variability in swimming parameters and body kinematics during social activity, as well as the uncertainty in how to quantify associated energetic expenditure, we group- 
Table 3. Inferred daily and seasonal time-activity budget for adult female North Atlantic right whales (NARWs). Note that annual phase durations are identical for resting and pregnant females. Travelling and socializing behaviour are grouped together under 'Travelling' for energy expenditure calculation

\begin{tabular}{|c|c|c|c|c|c|c|}
\hline \multirow[t]{2}{*}{ Annual phase } & \multicolumn{3}{|c|}{ 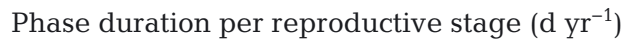 } & \multirow{2}{*}{$\begin{array}{l}\text { Foraging } \\
\text { time }\left(\mathrm{h} \mathrm{d}^{-1}\right)\end{array}$} & \multirow{2}{*}{$\begin{array}{l}\text { Travelling } \\
\text { time }\left(\mathrm{h} \mathrm{d}^{-1}\right)\end{array}$} & \multirow{2}{*}{$\begin{array}{l}\text { Resting time } \\
\qquad\left(\mathrm{h} \mathrm{d}^{-1}\right)\end{array}$} \\
\hline & Resting & Pregnant & Lactating & & & \\
\hline Sum & $261.5-296.9$ & $261.5-29$ & $2174-2$ & $.1^{\mathrm{c}}-17$. & $6.2^{\mathrm{d}}-8.3^{\mathrm{c}}$ & $0.6^{\mathrm{c}}$ \\
\hline $\mathrm{F}$ & & & & 0 & & 1 \\
\hline preeding & 26. & 26. & 78 & U & $21.4^{\mathrm{e}}$ & $4.1^{\mathrm{e}}$ \\
\hline Spring migration & $21-24^{\mathrm{b}}$ & $21-24^{\mathrm{b}}$ & $21-24$ & 0 & $20^{\mathrm{b}}$ & $4^{1}$ \\
\hline \multicolumn{7}{|c|}{$\begin{array}{l}\text { aKrzystan et al. (2018): modelled residency times on winter breeding grounds for non-calving (resting, pregnant) and calv- } \\
\text { ing (lactating) female NARWs }\end{array}$} \\
\hline \multirow{3}{*}{\multicolumn{7}{|c|}{$\begin{array}{l}\text { birestone et al. (2008): average migration time from Jacksonville, Florida, to the tip of Long Island, New York } \\
\text { (ca. } 1500 \mathrm{~km}) \text {; migration time is conceivably longer to the Gulf of St. Lawrence (GSL), but it is unknown whether whales } \\
\text { migrating further north would shorten their time on wintering grounds to compensate for longer transit times; until more } \\
\text { data on migration time from wintering grounds to the GSL become available, we have used published migration times } \\
{ }^{c} \text { Goodyear (1996): estimated mean daily activity budget from NARW tag data in the Bay of Fundy as: foraging (62.8\%; } \\
\left.15.07 \mathrm{~h} \mathrm{~d}^{-1}\right) \text {, socializing: }(18.15 \%) \text {, travelling }(15.8 \%) \text {, resting }\left(2.7 \% \text {; } 0.65 \mathrm{~h} \mathrm{~d}^{-1}\right) \text {, playing }(0.6 \%) \text {. For this model, we com- } \\
\left.\text { bined social, travel and play activity together: } 34.9 \% \text { (or } 8.38 \mathrm{~h} \mathrm{~d}^{-1}\right)\end{array}$}} \\
\hline & & & & & & \\
\hline & & & & & & \\
\hline \multirow{2}{*}{\multicolumn{7}{|c|}{$\begin{array}{l}\text { dParks et al. (2011): estimated mean daily activity budget from NARW tag data in the Bay of Fundy as: foraging }(71.7 \% \text {; } \\
\left.17.2 \mathrm{~h} \mathrm{~d}^{-1}\right) \text {, socializing: }(4.7 \%) \text {, travelling }(21.3 \%) \text {, resting }\left(2.37 \% ; 0.57 \mathrm{~h} \mathrm{~d}^{-1}\right) \text {. For this model, we combined social and } \\
\left.\text { travel activity together: } 26 \% \text { (or } 6.24 \mathrm{~h} \mathrm{~d}^{-1}\right)\end{array}$}} \\
\hline & & & & & & \\
\hline \multirow{4}{*}{\multicolumn{7}{|c|}{$\begin{array}{l}\text { eVermeulen et al. (2012): inferred from southern right whale Eubalaena australis activity budget on breeding ground. } \\
\text { Travel ( } 41 \% \text { ) and social }(42 \%) \text { activity grouped together and resting }(11 \%) \text { and 'other' }(6 \%) \text { activity grouped together. } \\
\text { Nousek McGregor (2010) found that tagged right whales on breeding grounds off Florida spend } 64.7 \% \text { of their time } \\
\text { (174/269 dives) presumably travelling (deeper and longer dives) and } 35.3 \%(95 / 269) \text { of their time either socializing or rest- } \\
\text { ing (shallower and shorter dives) }\end{array}$}} \\
\hline & & & & & & \\
\hline & & & & & & \\
\hline & & & & & & \\
\hline & & & & & & \\
\hline
\end{tabular}

ed travelling and socializing behaviour into 1 category, and assumed that our estimates of the energetic cost of travel captured both behaviours.

We calculated daily energy expenditure $\left(E_{\text {out }}, \mathrm{MJ}\right.$ $\mathrm{d}^{-1}$ ) for each reproductive state $k$ (resting, pregnant or lactating) as:

$$
E_{\text {out }_{k}}=\frac{\sum_{i=1}^{n} \sum_{a=1}^{n} T_{a i} \times M_{a}+E_{\text {repro }}}{T_{\mathrm{f}}}
$$

where $i$ is the season $(\mathrm{n}=4$; winter, spring, summer, fall), $a$ is the activity type ( $\mathrm{n}=3$; foraging, travelling/ socializing, resting), $T_{a i}$ is the number of daily hours spent in activity a during season $i, M_{a}$ is the activityspecific energy cost, $E_{\text {repro }}$ is the energy required for gestation or lactation per year, and $T_{\mathrm{f}}$ is the number of days spent foraging per year, inferred from observed right whale migration time and residency on wintering grounds (Table 3 ).

We used resting metabolic rate (RMR) as a proxy for basal metabolic rate (BMR) because BMR is difficult to measure under Kleiber standards for most marine mammals (e.g. ensuring individuals are motionless, thermoneutral, post-absorptive). We thus used the following allometric RMR relationship specific to marine mammals (Williams \& Maresh 2015) that is comparable to the widely-used BMR equation of Kleiber (1975) (95\% of BMR):

$$
\mathrm{RMR}=581 \mathrm{mass}^{0.68}
$$

where body mass is in $\mathrm{kg}$, and RMR is in $\mathrm{kJ} \mathrm{d}^{-1}$ (converted to MJ). An average body mass of $35000 \mathrm{~kg}$ was used for a $14 \mathrm{~m}$ long right whale ( 18 yr old; Moore et al. 2005). We held RMR constant because the magnitude of intraspecific variation in RMR for a given body mass is unknown for large whales. However, we acknowledge that more information on RMR in right whales would help refine future bioenergetic models.

The cost of travelling and foraging was estimated using published morphometric and kinematic parameters for North Atlantic right whales (Table 2). Four main forces act on pelagic swimming species: weight, buoyancy, propulsion (or thrust) and drag, where weight counteracts buoyancy and propulsion counteracts drag (reviewed by Fish 2000). Buoyancy force fluctuates with individual body condition, and can cycle through periods of higher buoyancy during blubber accumulation and lower buoyancy during blubber breakdown (Nousek-McGregor et al. 2014). To quantify buoyancy force, data are needed on animal blubber volume, tissue density, and volume of gas-filled cavities (Miller et al. 2004). Since this infor- 
mation was unavailable, we assumed that the energy expended by a positively-buoyant right whale to overcome buoyancy during dive descent by fluking is balanced by energy savings while gliding during ascent (Nousek-McGregor et al. 2014).

Propulsive power $\left(P_{\mathrm{p}}\right.$ in $\mathrm{J} \mathrm{s}^{-1}$, Eq. 6) depends on the hydrodynamic drag force $\left(F_{\text {drag }}\right.$ in $\left.N\right)$, swim speed $(U$, $\mathrm{m} \mathrm{s}^{-1}$ ) and energy transfer efficiency which includes both muscular (or metabolic) efficiency $\left(\eta_{\mathrm{m}}\right)$ and propulsive (or propeller) efficiency $\left(\eta_{p}\right)$. It differs with activity (e.g. travelling vs. foraging) and dive phase (descent, bottom, ascent and surface recovery), and can be multiplied by the estimated time (s) a whale spends in each activity per day (Table 3 ) to determine daily activity costs $\left(\mathrm{J} \mathrm{d}^{-1}\right)$. We calculated $P_{\mathrm{p}}$ separately for travelling and for each phase of a foraging dive using Eq. (6):

$$
P_{\mathrm{p}}=\frac{F_{\mathrm{drag}} U}{\eta_{\mathrm{m}} \eta_{\mathrm{p}}}
$$

where the magnitude of the drag force $\left(F_{\text {drag }}\right.$, Eq. 7$)$ depends on swim speed, body form, characteristics of the surrounding medium, proximity to boundaries such as the air-water interface, and the relative contribution of inertial, viscous and gravitational forces (Fish 1998). $F_{\text {drag }}$ on a moving right whale can be calculated as:

$$
F_{\text {drag }}=\frac{1}{2} \rho C_{\mathrm{D}} A U^{2} g \lambda \gamma
$$

where $\rho$ is the density of the surrounding medium (seawater), $C_{\mathrm{D}}$ is the dimensionless drag coefficient (see Eq. 8), and $A$ is the total wetted surface area $\left(\mathrm{m}^{2}\right)$, which can be approximated using an allometric relationship to body mass (Table 2). We increased the surface area $A$ by $5 \%$ for pregnant females based on aerial photogrammetric measurements and blubber thickness data (Nousek McGregor 2010). $U$ is the swim speed $\left(\mathrm{m} \mathrm{s}^{-1}\right), g$ is the added drag of appendages (flukes and flippers), $\lambda$ is the active-to-passive drag ratio, and $\gamma$ is the surface wave drag augmentation factor. For the latter 2 factors, body oscillation during active locomotion alters the hydrodynamics and drag regime around a moving body, and is quantified by $\lambda$. Whether active swimming increases or decreases overall drag relative to passive gliding in right whales is uncertain; we therefore assumed a conservative $\lambda=1$, comparable to previous bioenergetic studies on marine mammals (Aoki et al. 2011, P. Miller et al. 2012, Trassinelli 2016). Surface wave drag $(\gamma)$ affects animals swimming at or near the water surface and gradually decreases with depth, becoming negligible $(\gamma=1)$ at submergence depths greater than 3 times the maximum body diameter (Hertel 1969). Given the uncertainty regarding the influence of surface wave drag on right whale energy expenditure, we set $\gamma=1$ for our model.

We calculated the drag coefficient $\left(C_{\mathrm{D}}\right)$ by multiplying the skin friction coefficient (first expression in Eq. 8) by the body dimensions, also known as the 'form factor' (second expression in Eq. 8; Phillips et al. 2017):

$$
C_{\mathrm{D}}=\left(\alpha \operatorname{Re}^{\beta}\right) \times\left[1+1.5\left(\frac{L}{d}\right)^{-\frac{3}{2}}+7\left(\frac{L}{d}\right)^{-3}\right]
$$

where $L$ is the body length $(\mathrm{m}), d$ is the maximum body diameter $(\mathrm{m})$, and Re is the Reynold's number (Reynolds 1883; Eq. 9), which describes the flow regime around a body of length $L$ moving at speed $U$ $\left(\mathrm{m} \mathrm{s}^{-1}\right)$ through a medium with kinematic viscosity $v$ (Table 2):

$$
\operatorname{Re}=\frac{L U}{v}
$$

At high Reynold's numbers $\left(>5 \times 10^{6}\right)$, which is the case for right whales given their body size and typical swim speed, fluid flow around the body transitions from laminar to turbulent, and increases the value of the skin friction coefficient (Kline et al. 1967). Under a turbulent flow regime, the skin friction component of the drag coefficient $\left(C_{\mathrm{D}}\right)$ can be calculated using the constant $\alpha=0.072$ and the exponent $\beta=-0.2$ (as used by Phillips et al. 2017).

The drag force acting on a right whale during foraging is greater than during travelling, since openmouth feeding exposes a larger surface area to oncoming water flow, adding resistance to forward motion (Sanderson \& Wassersug 1990, Potvin \& Werth 2017). For a given speed, foraging increases the drag on a right whale by an estimated 2-3 times compared to travelling (Nousek McGregor 2010, Potvin \& Werth 2017). $F_{\text {drag }}$ (Eq. 7) was thus multiplied by 2 and 3 to obtain low and high estimates of energy expended during foraging.

Most deep-diving marine mammals use an intermittent swimming gait to conserve oxygen reserves, where active stroking is followed by periods of passive gliding. Certain species also increase time spent gliding during descent on deeper dives (Williams et al. 2000). On a foraging dive, right whales passively glide for an average $36 \%$ of descent time (range $10-75 \%), 30 \%$ of ascent time $(20-36 \%)$ and $9 \%$ of bottom time (6-12\%; Nowacek et al. 2001, Nousek McGregor 2010, Nousek-McGregor et al. 2014). The proportion of time right whales spend gliding during surface recovery and during travelling is unknown, 
so we assumed a similar glide time as during horizontal swimming during the bottom phase $(9 \%)$. We used average glide times and kept the proportion of time spent gliding in each phase constant with depth, as it is unknown how glide times vary with dive depth in right whales. The metabolic cost incurred during gliding likely falls between RMR and active propulsion. However, in the absence of data to inform the cost of this locomotory behaviour, we assumed energy expended during a passive glide is equivalent to RMR, recognizing that this may be an underestimate. Therefore, the total energetic cost (J, converted to $\mathrm{MJ}$ ) of travelling per day was calculated as:

$$
E_{\text {travel }}=P_{\mathrm{p}_{\text {travel }}} \times t_{\text {travel }} \times\left(1-t_{\text {glide }}\right)
$$

and the total cost ( $\mathrm{J}$, converted to $\mathrm{MJ}$ ) of foraging per day at depth $i$ as:

$$
E_{\text {forage }_{i}}=\left[\sum_{j=1}^{\mathrm{n}} P_{\mathrm{p}_{j}} \times t_{j} \times\left(1-t_{\text {glide }_{j}}\right)\right] \times \mathrm{n}_{\text {dives }}
$$

where $j$ is 1 of 4 dive phases, $P_{\mathrm{p}}$ is the propulsive power $\left(\mathrm{J} \mathrm{s}^{-1}\right)$ during dive phase $j, t_{\text {travel }}$ and $t_{j}$ are the times (s) spent travelling per day or in dive phase $j$ per dive, $t_{\text {glide }}$ is the proportion of time spent gliding. $\mathrm{n}_{\text {dives }}$ is the theoretical maximum number of dives $\mathrm{d}^{-1}$ at a given depth if foraging $\sim 15-17 \mathrm{~h} \mathrm{~d}^{-1}$ (Table 3), which would translate to daily ingestion (bottom) times of $\sim 5-10 \mathrm{~h} \mathrm{~d}^{-1}$, depending on reproductive state, daily foraging time and foraging depth. This is in accordance with an average daily ingestion time of $8.4 \mathrm{~h} \mathrm{~d}^{-1}$ reported from tagged North Atlantic right whales (Goodyear 1996).

Time (s) spent in ascent and descent phase was calculated as distance travelled $(\mathrm{m})$ divided by swim speed $\left(\mathrm{m} \mathrm{s}^{-1}\right)$ for each phase, where distance travelled is equal to dive depth $(\mathrm{m})$ corrected for average body pitch $(\theta)$ (Eq. 12). During foraging dives, adult female right whales pivot their body to around $69-78^{\circ}$ relative to the water surface on descent, and $56-68^{\circ}$ relative to the sea floor on ascent, depending in part on body condition (Nousek-McGregor et al. 2014). We used average angles of $74^{\circ}$ for descent and $62^{\circ}$ for ascent, and calculated distance travelled during descent or ascent phase as:

$$
\theta_{\text {descent or ascent }}=\frac{\text { Depth }}{\text { Distance }}
$$

Time spent in the bottom phase $\left(t_{\mathrm{b}}\right)$ for dive depths of $0-150 \mathrm{~m}$ was calculated according to the equation of Baumgartner et al. (2017) derived from tagging studies of North Atlantic right whales:

$$
t_{\mathrm{b}}=0.0704 \times \text { depth }
$$

Bottom time for dive depths of $160-500 \mathrm{~m}$ was assumed constant and equal to the maximum bottom time predicted by the previous equation $(t=636 \mathrm{~s})$. Time spent in the surface phase $\left(t_{\mathrm{s}}\right)$ was expressed as a percentage of the total time spent at depth, and was assigned an average value of $21.1 \%$ for resting females and $34.2 \%$ for pregnant or lactating females (Baumgartner \& Mate 2003).

The gestation period for right whales is about 12 mo (Knowlton et al. 1994). During this time, females allocate energy to foetal, uterine, placental and mammary tissue growth. Following parturition, mothers need energy to produce milk and provision their young until weaning. The maternal energy required for gestation is allometrically correlated with newborn body mass (Eq. 14), and this relationship has been used in several studies on cetacean energetics (e.g. Lockyer 1981, Fortune et al. 2013, New et al. 2013, Villegas-Amtmann et al. 2015):

$$
H_{\mathrm{g}}=4400 \operatorname{mass}_{\mathrm{nb}}{ }^{1.2}
$$

where $H_{\mathrm{g}}$ is the heat increment of gestation (in $\mathrm{kCal}$, converted to MJ using $1 \mathrm{kCal}=0.004184 \mathrm{MJ}$ ), and mass $_{\mathrm{nb}}$ is newborn mass $(\mathrm{kg})$.

The energetic cost of lactation is a combination of both mother and calf metabolism (Lockyer 1981). The nursing period for large mysticetes is around 6-7 mo (Oftedal 1997), and North Atlantic right whale mothers and calves remain together for 8-17 mo (Hamilton et al. 1995, Hamilton \& Cooper 2010). Calves may begin feeding on zooplankton as early as 8 mo old (Baumgartner \& Mate 2003). We estimated the cost of lactation by adding the average daily energy requirement of the calf (mean $\pm \mathrm{SD}=1767 \pm 261 \mathrm{MJ}$; Fortune et al. 2013) to the daily energy requirement of a lactating female, accounting for a milk transfer efficiency of $90 \%$ (Lockyer 1981). We assumed mothers provided $110 \%$ of the daily energy requirements of the calf for the first 6 mo after birth, followed by a linear decline in energy contribution (representing the gradual weaning period) up until $12 \mathrm{mo}$, at which point the calf was presumed to feed independently (New et al. 2013).

\subsection{Foraging habitat suitability}

We converted the 3D net energy field into a foraging habitat suitability grid for each year and reproductive state, as well as for all years combined. We 
first summed the number of $10 \mathrm{~m}$ depth bins with $E_{\text {net }}$ values $>0$ (where 0 is defined as energetic equilibrium) for each grid cell, then divided by the total number of depth bins per grid cell. This provided a relative and weighted measure of foraging value per cell, with a value of 1 signifying that $100 \%$ of the water column was predicted to have suitable prey densities. We then built composite maps by overlaying all 12 annual habitat suitability maps together (2006-2017), and counting the number of years each $10 \mathrm{~km}^{2}$ grid cell had a positive foraging value (comparable to Nelson et al. 2009). This provided information on which areas in the Gulf of St. Lawrence showed temporally persistent suitable habitat (defined as any $x y z 10 \mathrm{~km}^{2}$ location within the gulf where prey density exceeded the theoretical daily energy requirements for adult female North Atlantic right whales). We considered 2 scenarios which differed in terms of energy gain and expenditure, reflecting suboptimal (low energy gain for high energy expenditure) and optimal (high energy gain for low energy expenditure) habitat suitability in the Gulf of St. Lawrence (Tables $2 \& 3$; Table S1). Trends over the study period in the amount of suitable foraging habitat (i.e. the number of $10 \mathrm{~km}^{2}$ grid cells with at least one $10 \mathrm{~m}$ depth bin showing an $E_{\text {net }}>0$, corrected for sampling effort) were explored using Pearson's correlations. All analyses were performed in R version 3.6.1 (R Core Team 2020).

\section{RESULTS}

In total, 1543 stations were sampled for Calanus spp. abundance from 2006 to 2017 in the Estuary and Gulf of St. Lawrence. Sampling effort during early summer surveys of the southern gulf was relatively uniform across years. Effort was also relatively uniform during the late summer surveys from 2006 to 2014 primarily in the northern gulf, but was low in 2015 and 2017, and nonexistent in 2016 (Fig. 2, Table S2).

When predicting the 2D depth-integrated seasonal prey fields, the gamma distribution outperformed the exponential and lognormal distributions for the early-season Calanus spp. biomass, and all 3 distributions were comparable in terms of model fit and predictive performance for the late-season biomass data. The gamma distribution was chosen for prediction with the best-fitting model, which included additive smoothed effects of SST, slope, bathymetry and the spatial random effect.

In early summer, the sampled depth-integrated $\mathrm{Ca}$ lanus spp. biomass measurements ranged from 0 to $507.4 \mathrm{~g} \mathrm{DW} \mathrm{m}^{-2}$ for all years combined (range of medians: $0.1-17.6$, means: $0.7-32.9$, and SDs: $2.0-$ 67.7). In late summer, sampled biomass ranged from 0 to $244.9 \mathrm{~g} \mathrm{DW} \mathrm{m}^{-2}$ (range of medians: 7.6-28.9, means: 20.8-46.9, and SDs: 17.6-50.8). Predicted depth-integrated Calanus spp. biomass at the $10 \mathrm{~km}^{2}$ grid locations ranged from 0 to $506.4 \mathrm{~g} \mathrm{DW} \mathrm{m}^{-2}$ in early summer range of medians: $0.7-56.7$, means: 2.6-71.6, and SDs: $6.7-83.3$, and from 0.18 to $404.8 \mathrm{~g}$ DW $\mathrm{m}^{-2}$ in late summer (range of medians: 2.0-27.4, means: 13.8-43.7 and SDs: 11.3-54.0) (Table S3). The vertical distribution model, which predicted Calanus spp. biomass density in $10 \mathrm{~m}$ depth bins from surface to sea floor, produced values ranging from 0 to $6.0 \mathrm{~g}$ DW $\mathrm{m}^{-3}$ in early summer (range of medians: $0-0.7$, means: $0-1.4$, and SDs: $0.1-1.5$ ), and from 0 to $5.8 \mathrm{~g}$ DW $\mathrm{m}^{-3}$ in late summer (range of medians: $0.2-0.7$, means: $0.4-1.2$, and SDs: $0.4-1.4$ ).

Using the estimation and validation data subsets, observed depth-integrated Calanus spp. biomass values were correlated to predicted values with a mean \pm SD correlation coefficient of $0.61 \pm 0.11$ in the early season and $0.69 \pm 0.10$ in the late season. SST and slope did not significantly affect Calanus spp. biomass during the early or late season ( $95 \%$ confidence intervals overlapped 0 in all years). Unsurprisingly, bathymetry had little effect on Calanus spp. biomass values in the early season when $90 \%$ of the samples were collected in the southern Gulf of St. Lawrence at depths $<100 \mathrm{~m}$ (not shown). However, a positive effect was detected in the late season when Calanus spp. were sampled across a wider range of depths (40-450 m) (Fig. S1). We found a strong interannual variability in spatial correlation of Calanus spp. biomass values, with mean ranges of 71-434 km (median: 219, mean: 202, SD: 106) in the early season, and 53-1642 km (median: 133, mean: 376, SD: $506 \mathrm{~km}$ ) in the late season depending on the year. The degree of autocorrelation and uncertainty in predictions, expressed as the mean and SD posterior values for the spatial random effect, varied spatially and interannually (Figs. S2 \& S3).

Annual energy expenditure $\left(\mathrm{MJ} \mathrm{d}^{-1}\right)$ estimated for an adult female North Atlantic right whale in either a resting, pregnant or lactating reproductive state is summarized in Table 4. Assuming right whales spend 15-17 $\mathrm{h} \mathrm{d}^{-1}$ foraging during the summer, Fig. S4 shows the predicted daily ingestion time (h) when foraging at depths from 0 to $500 \mathrm{~m}$. It also shows the minimum predicted prey density requirement as a function of depth for each reproductive state. Prey biomass densities required to meet daily energy output ranged from 0.62 to 2.67 (median 1.34) $\mathrm{g} \mathrm{m}^{-3}$ for 
Table 4. Estimated daily energy expenditure $\left(\mathrm{MJ} \mathrm{d}^{-1}\right)$ for an adult female North Atlantic right whale in either a resting, pregnant or lactating reproductive state

\begin{tabular}{|lccc|}
\hline Reproductive state & Min. & Median & Max. \\
\hline Resting & 1355 & 1533 & 1726 \\
Pregnant & 1557 & 1855 & 2167 \\
Lactating & 3565 & 4233 & 4915 \\
\hline
\end{tabular}

resting females, from 0.79 to 3.72 (median 1.80) $\mathrm{g} \mathrm{m}^{-3}$ for pregnant whales and from 1.82 to 8.48 (median 4.11) $\mathrm{g} \mathrm{m}^{-3}$ for lactating whales. This translates to threshold abundance densities of $\sim 4470-6700$ ind. $\mathrm{m}^{-3}$ for resting, 6000-9000 ind. $\mathrm{m}^{-3}$ for pregnant and 13 700-20 550 ind. $\mathrm{m}^{-3}$ for lactating females if they fed only on C. finmarchicus/C. glacialis stage CV. Alternatively, required threshold abundances would be $\sim 610-790$ ind. $\mathrm{m}^{-3}$ for resting, $\sim 820-1060$ ind. $\mathrm{m}^{-3}$ for pregnant, and $\sim 1870-2420$ for lactating females feeding only on C. hyperboreus stage CI-V (using our median prey biomass density thresholds and the range of individual copepod dry weights summarized by Lehoux et al. 2020).

The depths associated with maximum $E_{\text {net }}$ values $\left(\geq 98^{\text {th }}\right.$ percentile) to support all 3 reproductive states of right whales were $50 \mathrm{~m}$ (median) in the early summer, and $220 \mathrm{~m}$ in late summer. These coincided with maximum Calanus spp. densities at $50 \mathrm{~m}$ in early summer in the shallow southern Gulf of St. Lawrence, and $230 \mathrm{~m}$ in late summer (when sampling effort was mainly in the deeper northern Gulf of St. Lawrence). The total percentage of $E_{\text {net }}$ values exceeding 0 within the 3D Calanus prey field was low, ranging from 1.0 to $6.5 \%$ for resting females, from 0.5 to $4.7 \%$ for pregnant females and from 0.01 to $0.9 \%$ for lactating females.

The location of suitable foraging habitat varied considerably from 2006 to 2017 (Fig. S5). As expected, more habitat was available to right whales under the optimal foraging scenario compared to the suboptimal scenario, and the amount of suitable habitat decreased as females went from resting, to pregnant, to lactating and their energy expenditure increased.

Suitable foraging habitat which met the energetic requirements of right whales in any reproductive state and across several years occurred in the southern Gulf of St. Lawrence. However, the spatial configuration and quantity of this habitat within the southern gulf fluctuated from year to year. Under an optimal foraging scenario, densities required to meet the needs of females with the lowest energy demands (i.e. resting females) occurred in $\geq 50 \%$ of the water column within some regions of the southern gulf over multiple years. These areas included Chaleur Bay, Shediac Valley and surrounding waters, the southern slope of the Laurentian Channel (to the north of the southern gulf), waters off the Gaspé Peninsula and around the Magdalen Islands, and the middle of the Magdalen Shallows (Fig. S5b).

Suitable foraging habitat became progressively more sparse from 2006 to 2017 , with little to no suitable habitat available after 2014 for all reproductive states unless foraging conditions were optimal (Fig. 3; Fig. S5). This pattern was particularly striking in the southern Gulf of St. Lawrence, with a significant decline in habitat suitability under both foraging scenarios (Pearson's R, all >0.63, all p < 0.05), when suitable habitat was available (i.e. none available for the 2006-2017 period for lactating females foraging under suboptimal conditions). In the northern gulf, the amount of suitable habitat available to right whales in any reproductive state remained relatively stable over the study period (Fig. 3; Pearson's R = $0.15-0.40$, all $p>0.05$ ). However, the location of suitable habitat within the northern gulf varied between years (Fig. S5). For instance, suitable prey densities to support resting right whales in 2008 and 2009 were spread in patches from the estuary to Anticosti Island, and to the west of Newfoundland. In comparison, 2007, 2013 and 2014 had fewer grid cells showing suitable prey densities, which were mostly scattered along the north shore of the Gulf of St. Lawrence (north of Anticosti) and into the northeast gulf, west of Newfoundland, although sampling coverage in the northern gulf was more variable compared to in the south (Fig. S5a,b).

Similar spatio-temporal patterns in suitable habitat were found for pregnant females (Fig. S5c,d). However, there were little to no suitable prey densities for pregnant females under the suboptimal scenario in 2010, 2013 and 2015-2017, except for a few grid cells along the southern slope of the Laurentian Channel $(2013$, 2016), and within the Strait of Belle Isle (2015) (Fig. S5c). For lactating females, predicted suitable habitat under optimal foraging conditions was largely concentrated in the southern gulf (2006-2009, 2011, 2012, 2014; Fig. S5f), with $\geq 50 \%$ of the water column containing suitable prey densities in the Shediac Valley area, around the Magdalen Islands, occasionally along the northwest tip of Prince Edward Island and south of Miramichi Bay. Only in 3 years $(2006,2007,2011)$ were there sufficient prey densities to support the energy requirements of lactating females foraging under suboptimal conditions, albeit a very low number of grid cells. All of these sites were in the southern gulf (Fig. S5e). 
A

Early season

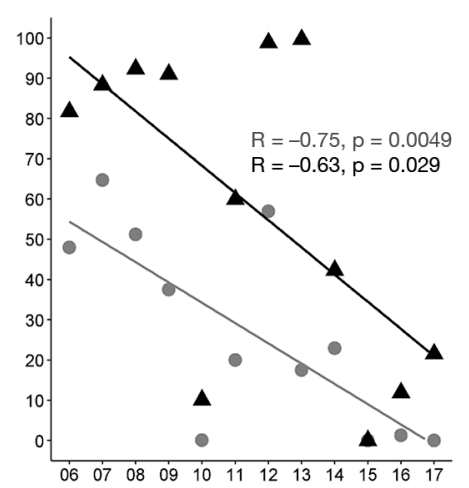

Late season

Resting

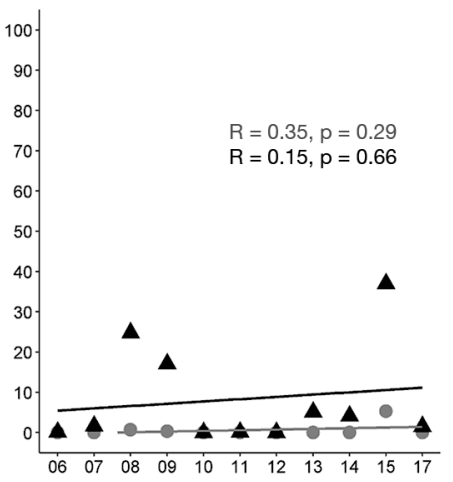

Pregnant

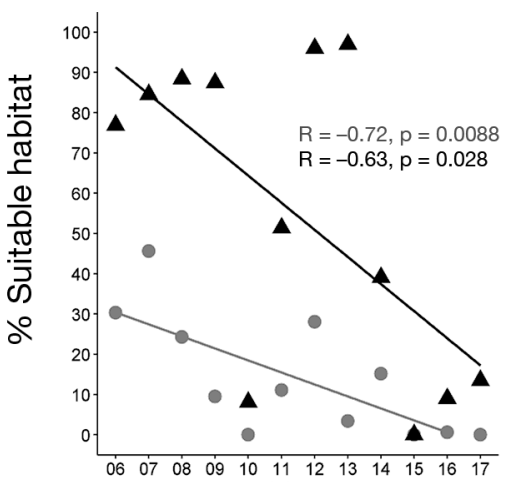

C

Lactating

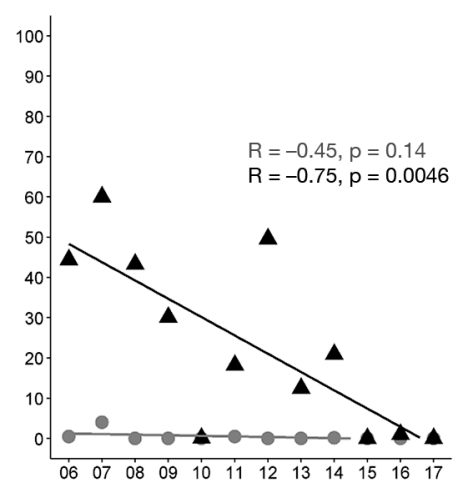

Year

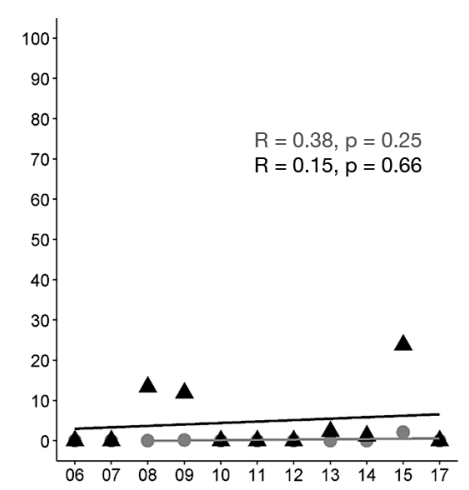

\section{DISCUSSION}

We predicted locations of suitable foraging habitat for North Atlantic right whales within the Gulf of St. Lawrence by combining ecophysiological data (morphology, physiology, behavioural ecology, kinematics, and energetics) with 3-dimensional prey fields reflecting over a decade of temporal variability in prey densities and distributions. We found that the most suitable habitat for resting, pregnant and lactating right whales occurred in the southern Gulf of St. Lawrence, which was consistent with the distribution of right whale sightings found during recent systematic surveys in the gulf (DFO 2019a, 2020), as well as with habitat predictions drawn from the spatial climatology of Calanus spp. biomass (Plourde et al. 2019).

\subsection{Copepod biomass and distribution}

Right whales are known to exploit energetically rich, diapausing latestage copepods during the summer

Composite maps of all years showed a broad area in the southern Gulf of St. Lawrence that had suitable prey densities (i.e. with grid cells having at least one $10 \mathrm{~m}$ depth bin with prey densities exceeding thresh-
(Baumgartner \& Mate 2003). Diapausing Calanus spp. in the North Atlantic can occur within a broad range of temperatures, salinities and densities (reviewed by Krumhansl et al. 2018), although they 

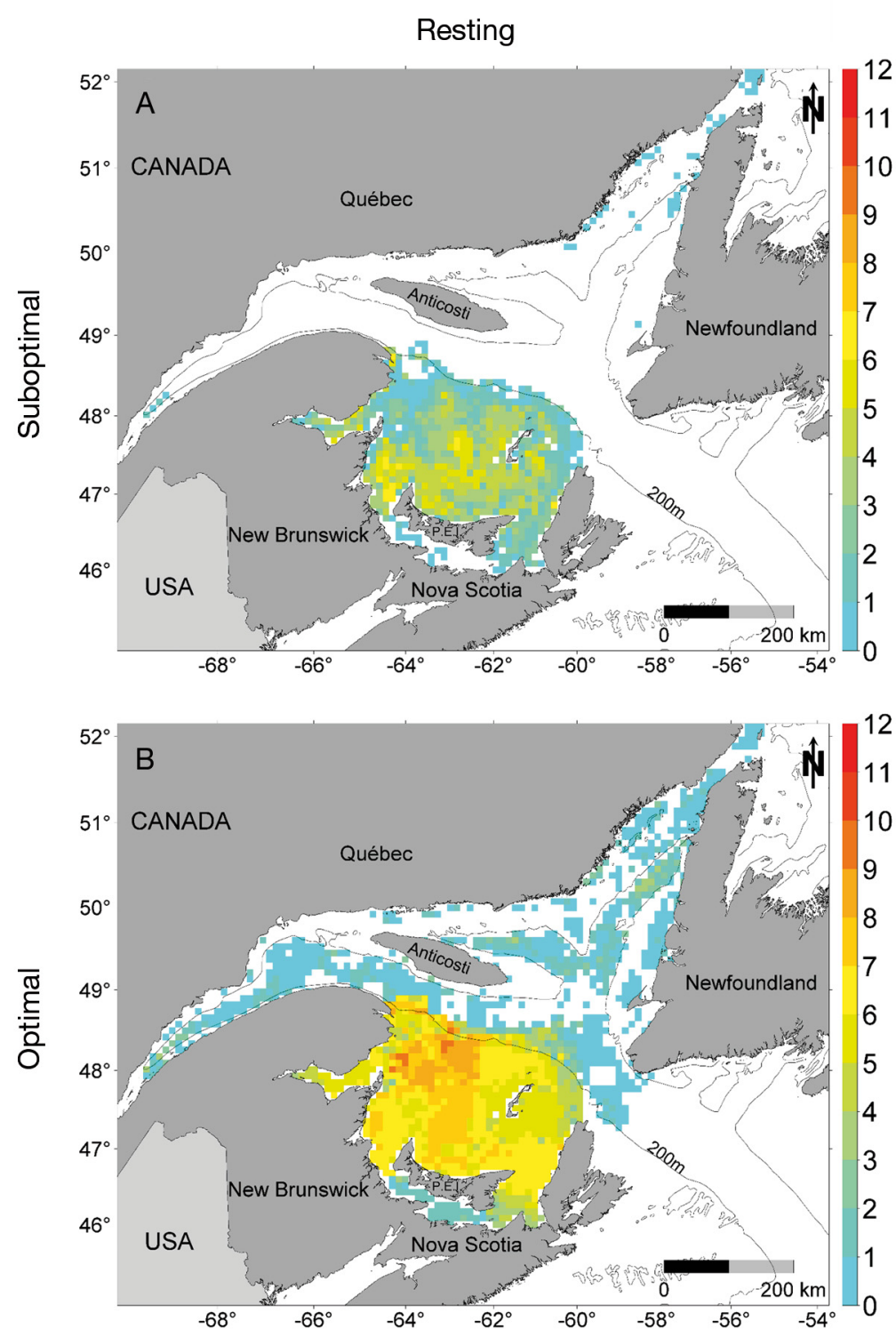

Fig. 4. Persistent suitable foraging habitat in the Gulf of St. Lawrence from June to September 2006-2017 for resting North Atlantic right whales under (A) suboptimal and (B) optimal foraging scenarios. Scale shows the number of years a given grid cell had at least one $10 \mathrm{~m}$ depth bin with suitable prey density

are routinely below the cold intermediate layer (Albouy-Boyer et al. 2016, Krumhansl et al. 2018).

In the southern Gulf of St. Lawrence, where densities of Calanus copepods suitable to support right whales were consistently predicted across the study period (2006-2017), the bathymetry is characterized by a broad, shallow shelf known as the Magdalen Shallows, which varies in depth from 60 to $80 \mathrm{~m}$. C. finmarchicus and C. hyperboreus in this region are mainly transported from deeper regions (Zakardjian et al. 2003, Brennan et al. 2019), and are concentrated in shallower-than-normal waters during diapause, which compresses them against the sea floor (Kaartvedt 1996, Krumhansl et al. 2018). Under such conditions, maximum Calanus spp. biomass densities ( $\mathrm{g} \mathrm{m}^{-3}$ in $10 \mathrm{~m}$ depth strata) can be 56 times greater at a $60 \mathrm{~m}$ deep station (southern gulf) than at a $300 \mathrm{~m}$ station in the deep Laurentian Channel (Plourde et al. 2019). A combination of concentrated Calanus spp. layers and shorter transit times to access this food source may thus provide advantageous foraging conditions for right whales, and might also explain why such a broad area of the southern Gulf had suitable prey densities across multiple years.

The copepod biomass in the Gulf of St. Lawrence is predominantly C. hyperboreus (Sorochan et al. 2019), a species of unknown dietary contribution to right whales. This species declined in abundance from 2006 to 2017 in the southern Gulf of St. Lawrence and largely drove our conclusion that right whale habitat quality declined over time. Further north in the gulf, densities of C. hyperboreus re-

appear to favour depths with colder and denser waters, with temperatures $<5^{\circ} \mathrm{C}$ considered optimal for diapause (Saumweber \& Durbin 2006). In the Gulf of St. Lawrence, the water column during the summer is highly stratified and includes a cold intermediate layer $\left(<1^{\circ} \mathrm{C}\right)$, which is on average 50-100 m deep (Gilbert \& Pettigrew 1997, Galbraith et al. 2019). In this region, the maximum abundance of diapausing C. finmarchicus and C. hyperboreus likely occurs in the deep channels and basins (such as the Laurentian Channel and Esquiman Channel) at depths that mained relatively unchanged or were slightly higher during this period (Lehoux et al. 2020).

A similar conclusion about habitat quality for right whales in the gulf can be drawn from the densities of C. finmarchicus, which were low throughout the 2006-2017 period (Lehoux et al. 2020). Therefore, there is no clear indication that feeding conditions notably improved for right whales in the Gulf of St. Lawrence in the later years of our study, although they may have been better than in other foraging habitats. This aligns with the observation that $C$. fin- 

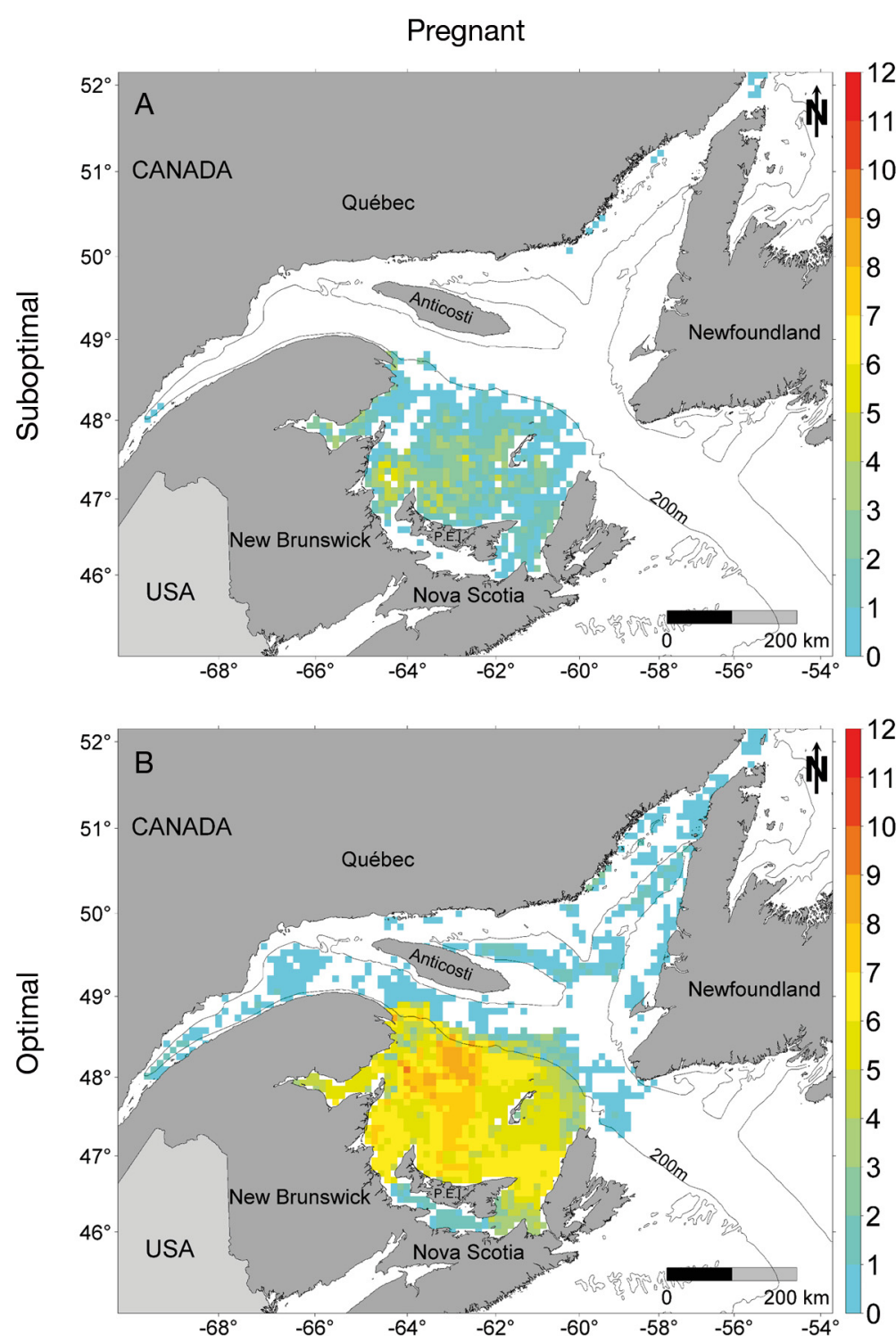

Fig. 5. Persistent suitable foraging habitat in the Gulf of St. Lawrence from June to September 2006-2017 for pregnant North Atlantic right whales under (A) suboptimal and (B) optimal foraging scenarios. Scale shows the number of years a given grid cell had at least one $10 \mathrm{~m}$ depth bin with suitable prey density

marchicus and C. hyperboreus biomass has decreased everywhere in the Gulf of Maine and eastern Canadian shelf waters since around 2010, whereas their biomass remained higher on average in the Gulf of St. Lawrence than in other feeding areas of North Atlantic right whales over the period 19792016 (Sorochan et al. 2019).

The southern gulf represents a population sink for Calanus spp. which must be re-populated in the spring of each year by transport of the new generation from the deep northern gulf (Runge et al. 1999, Za- kardjian et al. 2003, Blais et al. 2019, Brennan et al. 2019). Given that Calanus spp. abundance in the northern gulf did not substantially fluctuate between 2006-2010 and 2011-2017 (Blais et al. 2019, Lehoux et al. 2020), interannual changes in circulation patterns likely drove the decreased biomass of Calanus spp. observed in the southern gulf (Galbraith et al. 2019). These changes in circulation patterns in the southern gulf likely stem from variations in local winds and freshwater runoff from the St. Lawrence River (and from other major tributaries) during spring.

The decline in Calanus spp. abundance in traditional feeding areas corresponds to a period of lower right whale calving rates and reduced use of these areas (Davis et al. 2017, Davies et al. 2019). Under such conditions, exploratory movements from a larger number of right whales seeking alternative feeding areas would be expected. Such exploratory behaviour may explain the increased acoustic detections of right whales in the Gulf of St. Lawrence since at least 2015 (Simard et al. 2019), as well as the recent abundance indices from systematic aerial surveys that suggest $40-50 \%$ of the right whale population visited the Gulf of St. Lawrence at some point in 2018 and 2019 (DFO 2020). Thus, the increased use of the Gulf of St. Lawrence by right whales in recent years does not necessarily mean they have found good habitat, given our finding that the availability of Calanus copepods in the gulf may be insufficient to allow for successful reproduction of North Atlantic right whales - a conclusion that is consistent with the continued low calving rates of this population.

\subsection{Factors influencing right whale energy requirements}

With their specialized ram filter-feeding strategy, right whales rely on the environment to concentrate their prey into energetically profitable layers. Density of prey organisms can thus be a key driver of foraging behaviour (Kraus \& Rolland 2007). Right whales have been observed to cease foraging when prey densities fall below a certain range (Baumgartner \& 


\section{Lactating}
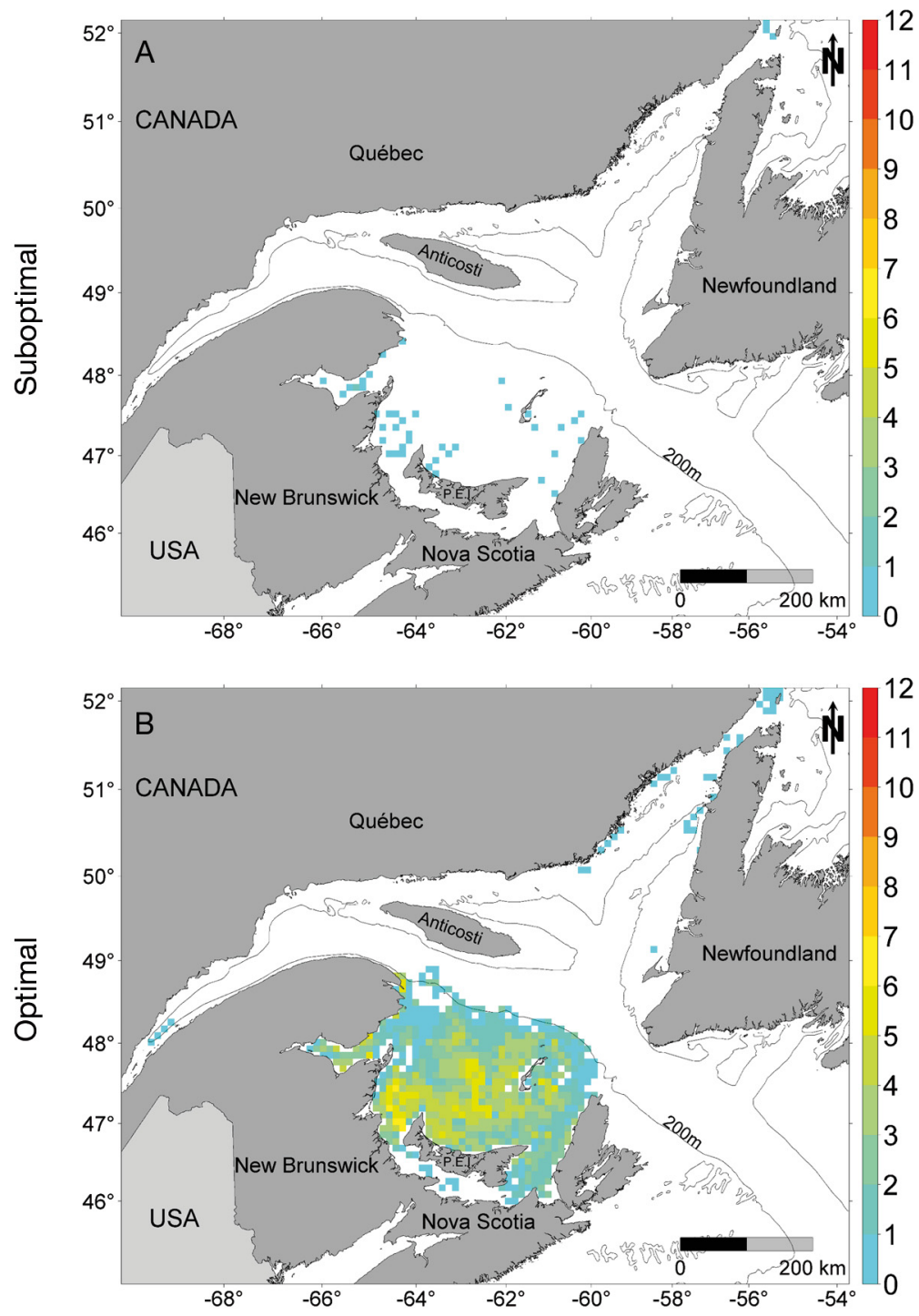

Fig. 6. Persistent suitable foraging habitat in the Gulf of St. Lawrence from June to September 2006-2017 for lactating North Atlantic right whales under (A) suboptimal and (B) optimal foraging scenarios. Scale shows the number of years a given grid cell had at least one $10 \mathrm{~m}$ depth bin with suitable prey density

Mate 2003). These threshold prey densities appear to range from 800 to 4000 copepods $\mathrm{m}^{-3}$, or $0.2-2.4 \mathrm{~g}$ $\mathrm{m}^{-3}$ depending on the average dry weights of different-sized C. finmarchicus C5 copepods $(0.0002-$ $0.0006 \mathrm{~g}$ dry; Table 5). These minimum prey density estimates (recorded in the vicinity of foraging right whales in the Northwest Atlantic) are consistent with our findings (assuming 1 copepod weighs $\sim 0.0006 \mathrm{~g}$ ).

Optimal prey density likely fluctuates with prey quality. In our case, we used a range of energy content values for late-stage $C$. finmarchicus and $C$. hyperboreus to predict minimum prey densities for right whales. However, feeding on more or less nutritive prey sources throughout the year would influence our predictions for where suitable foraging habitat occurs for right whales.

Reductions in copepod size and energy content are likely to occur as environmental conditions continue to warm (e.g. McKinstry et al. 2013). This phenomenon appears to be underway in the Gulf of St. Lawrence, particularly in the southern gulf, where warmer sea temperatures correlate with reduced body sizes of $C$. finmarchicus during the summer months (when body sizes since 2013 are compared with the previous 2 decades; Sorochan et al. 2019). Feeding on smaller and less energetically rewarding copepods might mean that right whales would have to spend more time foraging, and more time finding areas that have higher-quality prey patches.

Changes in copepod community composition are expected to occur as the ocean warms, while copepod species that are typical of temperate latitudes are predicted to expand their range northward. This gradual change toward a more temperate copepod community is being observed on the Scotian Shelf and to a lesser extent in the Gulf of St. Lawrence (Blais et al. 2019, DFO 2019b). However, these new species of copepods are unlikely to be a high-quality food for right whales because they are smaller and have a lower lipid content (see Lehoux et al. 2020). Moreover, the low filtering efficiency of right whale baleen to trap these smaller copepod species (unless they occur in exceptional densities) is likely a disadvantage to exploiting these new food sources (Mayo et al. 2001).

Some of the densest euphausiid (krill) aggregations in the Gulf of St. Lawrence have been reported in the areas we identified as being suitable for North Atlantic right whales to forage (McQuinn et al. 2015, Plourde et al. 2016). However, there is limited evidence that right whales feed on euphausiids (except in the Antarctic where they occur in extreme densities, as reviewed by Wade et al. 2011; see also Tormosov et al. 1998), even though both euphausiids and copepods have been detected near feeding right whales in the North Atlantic and North Pacific, as 
Table 5. Minimum prey density (copepods or organisms $\mathrm{m}^{-3}$ ) thresholds measured around North Atlantic right whales feeding primarily on late-stage (CIV-V) Calanus finmarchicus. Calculated biomass density threshold $\left(\mathrm{g} \mathrm{m}^{-3}\right)$ is based on individual $C$. finmarchicus CV dry weights of either 0.0002 or $0.0006 \mathrm{~g}$ (Davies et al. 2012). BoF: Bay of Fundy, CCB: Cape Cod Bay, GoM: Gulf of Maine, RB: Roseway Basin

\begin{tabular}{|c|c|c|c|c|}
\hline Reference & Location & $\begin{array}{c}\text { Density threshold } \\
\text { (copepods or organisms } \mathrm{m}^{-3} \text { ) }\end{array}$ & $\begin{array}{l}\text { Density threshold } \\
\quad\left(\mathrm{g} \mathrm{m}^{-3}\right)\end{array}$ & $\begin{array}{l}\text { Copepod } \\
\text { weight }(g)\end{array}$ \\
\hline Murison \& Gaskin (1989) & $\mathrm{BoF}$ & 820 copepods & $\begin{array}{l}0.2 \\
0.5\end{array}$ & $\begin{array}{l}0.0002 \\
0.0006\end{array}$ \\
\hline Mayo \& Marx (1990) & $\mathrm{CCB}$ & 1000 organisms & $\begin{array}{l}0.2 \\
0.6\end{array}$ & $\begin{array}{l}0.0002 \\
0.0006\end{array}$ \\
\hline Mayo \& Goldman (1992) ${ }^{\mathrm{a}}$ & GoM & 4000 copepods & $\begin{array}{l}0.8 \\
2.4\end{array}$ & $\begin{array}{l}0.0002 \\
0.0006\end{array}$ \\
\hline Wishner et al. (1995) & GoM & 1023-9749 copepods & $\begin{array}{l}0.2-2.0 \\
0.6-5.8\end{array}$ & $\begin{array}{l}0.0002 \\
0.0006\end{array}$ \\
\hline Beardsley et al. (1996) & GoM & $1500-4500$ copepods & $\begin{array}{l}0.3-0.9 \\
1.0-3.0\end{array}$ & $\begin{array}{l}0.0002 \\
0.0006\end{array}$ \\
\hline Baumgartner \& Mate (2003) & BoF \& RB & 3000 copepods & $\begin{array}{l}0.6 \\
1.8\end{array}$ & $\begin{array}{l}0.0002 \\
0.0006\end{array}$ \\
\hline
\end{tabular}

well as in stomach contents (Wade et al. 2011). A study examining habitat suitability using the same bioenergetics model we used for North Atlantic right whales concluded that euphausiids are unlikely to be an important prey in the Gulf of St. Lawrence if right whales pursue them at their usual swim speeds (Lehoux et al. 2020).

Right whales employ a foraging tactic (slow ram feeding) that is very different from krill-eating predators such as blue and fin whales (rapid-acceleration lunge feeding; Goldbogen et al. 2017). Right whales would need to swim at speeds approximately 5 knots faster than their usual speed to efficiently capture euphausiids (Hamner et al. 1988) - a behaviour undocumented in North Atlantic right whales (Murison \& Gaskin 1989, Wade et al. 2011). Southern right whales, however, are able to effectively exploit Euphausia superba (Hamner et al. 1988, discussed by Harcourt et al. 2019) due perhaps to E. superba having different evasive and swarming behaviours, and/or higher biomass compared to krill species in the western North Atlantic (Tarling \& Fielding 2016).

Fully determining the suitability of euphausiids as a food source for North Atlantic right whales will require assessing whether the energy they might gain from feeding on observed densities of krill can be balanced with the increased energy (associated with swimming at faster speeds) they would have to expend to capture it. Right whale dietary studies in the Gulf of St. Lawrence would also help support or refute our assumption that right whales feed primarily on late-stage Calanus spp., and are not adapted to consume euphausiids. Conceivably, additional foraging habitat could be exploited if right whales were to also opportunistically feed on krill (likely juvenile stages) in the Gulf of St. Lawrence. Bioenergetic modelling to help answer these questions can be further refined by incorporating information on prey species being targeted, as well as threshold, average and maximum prey densities sampled in the vicinity of foraging right whales on this feeding ground.

We chose to model the energy requirements of a $14 \mathrm{~m}$ adult female weighing $35000 \mathrm{~kg}$ based on the morphometric findings of Moore et al. (2005), and used average calf mass at birth from Fortune et al. (2012) to estimate the cost of pregnancy. Our model did not account for growth in mass, which, although small, still exists for adult animals (Fortune et al. 2020b). Recently updated growth models for North Atlantic right whales using a broader dataset of necropsied individuals predicted shorter mean lengths $(\sim 13.5 \mathrm{~m})$ for adults weighing $35000 \mathrm{~kg}$, and a slightly lower mean mass at birth (Fortune et al. 2020b). In performing a sensitivity analysis, we found that reducing adult body length by $0.5 \mathrm{~m}$ and reducing birth mass had little effect on energy expenditure estimates and had no effect on minimum prey density requirements, suggesting that our model is robust in capturing energy requirements for a greater range of adult lengths and calf masses.

Our mean estimates of annual energy expenditure for all 3 right whale reproductive states (1533$4233 \mathrm{MJ} \mathrm{d}^{-1}$ ) are comparable to energetic requirements estimated for right whales in previous studies 
(closer to the lower range of the estimates of Kenney et al. 1986: 1703-17 $322 \mathrm{MJ} \mathrm{d}^{-1}$; Baumgartner \& Mate 2003: $1659 \mathrm{MJ} \mathrm{d}^{-1}$; Fortune et al. 2013: 1013$5738 \mathrm{MJ} \mathrm{d}^{-1}$ ). Adult male right whales require $\sim 6 \%$ less energy than resting adult females due to differences in body composition and lower residency times on breeding grounds (Fortune et al. 2013). Although we did not include adult males in our study, their lower daily energy requirements would likely have resulted in more suitable foraging habitat being available to males than to adult females in the Gulf of St. Lawrence.

In our model, we assumed that the energy requirement of a lactating female was a combination of her metabolism and that of her calf. Some lactating mothers may be unable to meet their daily energy requirements to arrive at zero or positive energy balance, resulting in reduced body condition that will take $>1$ recovery year for them to rebuild lipid stores and support another pregnancy. This means that prey densities that are 'good enough' to support calf growth and mother survival for 1 feeding season, may not cover the actual energy requirements of lactation and may result in an energy deficit that mothers will pay at a later date (C. Miller et al. 2012, Christiansen et al. 2020). Unfortunately, the minimum daily energy intake needed to support a lactating female over the course of lactation, and the duration a negative energy balance (i.e. weight loss) could be sustained are unknown.

Females presumably have some plasticity in their reproductive behaviour to optimize their survival and that of their offspring. Females with calves may thus employ adaptive strategies that go beyond our model assumptions to cope with instability in foraging conditions. They may, for example, catabolize their energy stores to help offset any energetic imbalance, extend time on feeding grounds to maximise food intake, reduce the number of hours spent foraging per day to reduce energy expenditure, forego migration to reduce travel costs, shorten or extend the lactation period depending on their provisioning strategy and/or extend their inter-calving interval to permit sufficient time to replenish their energy stores.

Other factors contributing to annual energy balance are daily and seasonal activity budgets, namely how much time is spent engaged in various behavioural states, and how this varies over the course of the year. The time-activity budget in our bioenergetics model (Table 3) was based on studies of right whale behaviour, migratory movements and residency times on wintering grounds in southeastern US waters. Gowan et al. (2019) showed that use of these wintering grounds varies considerably from year to year and across demographic groups, and that the probability of migration increases in years following higher $C$. finmarchicus abundance. Thus, reproductively mature females may choose to remain in northern latitudes during the fall, winter and spring, to maximise potential feeding opportunities and improve body condition.

In the absence of data on right whale activity budgets during the non-summer months in northern latitudes, or knowing what prey densities may be available, it is difficult to infer what effect continued occupancy of northern latitudes throughout the year would have on suitable habitat predictions in the Gulf of St. Lawrence. It would be informative to evaluate energy returns for whales that remain in northern latitudes and continue to feed in non-summer months given that foraging is more costly than travelling. We cannot dismiss the possibility that the overall daily energy requirements of right whales may be reduced in years when reproductive females choose to skip migration, potentially opening up more suitable foraging areas in the Gulf of St. Lawrence compared to our predictions. More information is therefore needed on right whale occurrence, residency and habitat use in northern latitudes such as the Gulf of St. Lawrence, Scotian Shelf and Newfoundland waters throughout the year (DFO 2019a, 2020).

Energy intake that our modelled right whales required partly depended on the number of hours per day and the number of days per year spent foraging. We assumed they spent a constant number of hours feeding per day (within a range of values) based on prior studies. In reality, however, whales may not feed for a day or more while looking for food, and may spend more hours per day feeding once a highquality food patch is found (e.g. Fortune et al. 2020a).

Without information on the daily activity budgets of right whales in the Gulf of St. Lawrence, we believe the range of daily foraging times we used from elsewhere in the right whale range were reasonable reflections of average times spent feeding over the season and were comparable to daily feeding times recorded for other baleen whales (HeideJørgensen et al. 2013). However, this assumption would benefit from validation with field observations. In the same vein, we assumed that right whales were physiologically capable of foraging at depths below maximum observed foraging depths in other habitats (ca. 130-140 m; Nousek McGregor 2010, Baumgartner et al. 2017). Evidence from bowhead whales Balaena mysticetus suggests that this is a plausible assumption. Bowhead whales share similar 
morphological and ecological characteristics with right whales, and have been observed performing U- and square-shaped dives (presumed foraging) to a maximum depth of $650 \mathrm{~m}$, and V-shaped dives (presumed exploratory) to a maximum of $582 \mathrm{~m}$ (Heide-Jørgensen et al. 2013, Fortune et al. 2020a). Similar field studies are needed to document average and maximum depths of foraging dives in the Gulf of St. Lawrence, as well as determine how right whales use the water column throughout the season.

\subsection{Comparing suitable habitat predictions to sightings data}

Using the reproductive success of North Atlantic right whale females that visited the Gulf of St. Lawrence to validate our habitat suitability predictions is challenging because few systematic surveys were undertaken to locate and identify individual right whales in the Gulf of St. Lawrence until 2015. Unfortunately, the most extensive and sustained surveys were undertaken in this region following the die-off of multiple North Atlantic right whales in June 2017 (Daoust et al. 2017). Thus, there are insufficient sightings data to reliably compare the reproductive success of mature females that frequented the gulf with the predictions of our habitat suitability model (for the period 2006-2017).

Sightings data from 2017 and 2018 indicate that approximately one-third of reproductively mature female right whales (i.e. those that have calved at least once) visited the Gulf of St. Lawrence, albeit for an unknown duration (Table 6; Pettis et al. 2020, Right Whale Consortium 2020). Thus, despite the increase in right whale acoustic detections since 2015 (Simard et al. 2019), and the relatively high number of right whales identified during systematic surveys since 2017 (both suggesting an increase in occupancy of the Gulf of St. Lawrence by this population), the continued low calving rates suggest that increased use of the Gulf of St. Lawrence has not resulted in higher reproductive success in recent years. This is consistent with our conclusion that foraging conditions in the gulf were not favourable for right whale reproduction during the later years of our time series.

The fact that few females with calves have been observed within the gulf since 2016 (Table 6) could imply that prey densities were still worth feeding on, but were insufficient to maintain net 0 or positive energy balance, which may explain the longer postlactation recovery periods and calving intervals (mean calving interval was $7 \mathrm{yr}$ in 2019 compared to their historic 3 yr calving cycle; Knowlton et al. 1994, Pettis et al. 2020). Another factor contributing to the lower calving rates and longer calving intervals of some females could be the added energetic burden of chronic entanglement in fishing gear-a plight which many individuals encounter (van der Hoop et al. 2017a). Conducting regular systematic surveys to determine the number, demography and residency period of right whales in the Gulf of St. Lawrence would help to assess these possibilities and further test the validity of our habitat suitability predictions.

Table 6. Total number of reproductively mature female North Atlantic right whales (i.e. those that calved at least once), total number of calves and total number of resting (Rest), pregnant (Preg) and lactating (Lact) females in the population from 2016 to 2019, as well as total number of mature females seen in the Gulf of St. Lawrence (GSL) in 2017-2018. Numbers of resting, pregnant, and lactating females in the GSL are shown both in absolute number and relative (\%) to the total number of females in this reproductive state (in parentheses). Lactating females are those in repeatedly close association with a calf, and pregnant females are those seen with a calf the following year (and thus does not account for potential reproductive failure).

NA: proportion invalid given the divider was zero. Data from Pettis et al. (2020) and Right Whale Consortium (2020)

\begin{tabular}{|c|c|c|c|c|c|c|c|c|c|c|}
\hline Year & $\begin{array}{l}\text { Total F } \\
\text { mature }\end{array}$ & $\begin{array}{c}\text { Total } \\
\text { calves }\end{array}$ & $\begin{array}{l}\text { Total } \\
\text { Rest }\end{array}$ & $\begin{array}{l}\text { Total } \\
\text { Preg }\end{array}$ & $\begin{array}{l}\text { Total } \\
\text { Lact }\end{array}$ & $\begin{array}{l}\text { Mature F } \\
\text { GSL }\end{array}$ & $\begin{array}{l}\text { Mature F GSL / } \\
\text { Total mature F }\end{array}$ & $\begin{array}{l}\text { Rest } \\
\text { GSL }\end{array}$ & $\begin{array}{l}\text { Preg } \\
\text { GSL }\end{array}$ & $\begin{array}{l}\text { Lact } \\
\text { GSL }\end{array}$ \\
\hline $2016^{a}$ & 85 & 14 & 66 & 5 & 14 & $\mathrm{a}$ & $\mathrm{a}$ & $\mathrm{a}$ & a & $\mathrm{a}$ \\
\hline 2017 & 71 & 5 & 66 & 0 & 5 & 25 & 0.35 & 25 (38) & 0 (NA) & $0(0)$ \\
\hline 2018 & 76 & 0 & 69 & 7 & 0 & 25 & 0.33 & $21(30)$ & $4(57)$ & 0 (NA) \\
\hline $2019^{b}$ & 87 & 7 & b & b & 7 & b & b & b & b & b \\
\hline
\end{tabular}




\subsection{Conclusions}

Examining interannual variations of the 3dimensional Calanus spp. prey field in the Gulf of St. Lawrence (2006-2017) relative to the energetic needs of reproductively mature female North Atlantic right whales indicates that prey densities should have been sufficient to support resting, pregnant and lactating females in most $(\geq 6)$ years in the southern gulf (from Shediac Valley to the Magdalen Islands). However, we identified few other suitable foraging areas elsewhere in the gulf to support these 3 reproductive stages and noted a significant decline in habitat quality after 2014 (particularly for lactating females) due to reduced Calanus spp. biomass in the southern gulf.

As ocean temperatures continue to rise, negative trends in both the occurrence and abundance of C. finmarchicus are anticipated at the southern edge of its range (Reygondeau \& Beaugrand 2011, Villarino et al. 2015, Grieve et al. 2017). In the Gulf of St. Lawrence, increasing bottom water temperatures (Galbraith et al. 2019) might exceed thermal optima for C. finmarchicus and C. hyperboreus (Reygondeau \& Beaugrand 2011), potentially compromising the suitability of this foraging area for North Atlantic right whales. Shelf waters off Newfoundland and Labrador might offer a more thermally stable habitat for C. finmarchicus compared to other areas (Loder \& Wang 2015, Saba et al. 2016), where densities of C. finmarchicus have been comparable or higher than those reported for the Gulf of Maine and Gulf of St. Lawrence (Sorochan et al. 2019), and are likely to remain a habitat for this species in the future (Reygondeau \& Beaugrand 2011).

Long-lived migratory megafauna such as whales that rely on memory of long-term average phenologies to locate quality food patches will need to adapt to altered distributions and abundances of key forage species (Abrahms et al. 2019). Varying patterns in North Atlantic right whale seasonal movements over the past decade are likely responses to shifts in prey distribution, emphasizing the need to identify areas of frequent use, where novel and dynamic management strategies should be implemented to reduce anthropogenic mortality and preserve areas that support vital functions.

Acknowledgements. We thank the North Atlantic Right Whale Consortium for access to the sightings data reported in this study, as well as Julie van der Hoop and 3 anonymous reviewers for valuable advice and suggestions. This work was supported by the Species at Risk program of Fisheries and Oceans Canada.

\section{LITERATURE CITED}

Abrahms B, Hazen EL, Aikens EO, Savoca MS and others (2019) Memory and resource tracking drive blue whale migrations. Proc Natl Acad Sci USA 116:5582-5587

Albouy-Boyer S, Plourde S, Pepin P, Johnson CL and others (2016) Habitat modelling of key copepod species in the Northwest Atlantic Ocean based on the Atlantic Zone Monitoring Program. J Plankton Res 38:589-603

Aoki K, Watanabe YY, Crocker DE, Robinson PW and others (2011) Northern elephant seals adjust gliding and stroking patterns with changes in buoyancy: validation of atsea metrics of body density. J Exp Biol 214:2973-2987

Baumgartner MF, Mate BR (2003) Summertime foraging ecology of North Atlantic right whales. Mar Ecol Prog Ser 264:123-135

*Baumgartner MF, Wenzel FW, Lysiak NSJ, Patrician MR (2017) North Atlantic right whale foraging ecology and its role in human-caused mortality. Mar Ecol Prog Ser 581:165-181

* Beardsley RC, Epstein AW, Chen C, Wishner KF, Macaulay MC, Kenney RD (1996) Spatial variability in zooplankton abundance near feeding right whales in the Great South Channel. Deep Sea Res II 43:1601-1625

Blais M, Galbraith PS, Plourde S, Scarratt M, Devine L, Lehoux C (2019) Chemical and biological oceanographic conditions in the Estuary and Gulf of St. Lawrence during 2018. DFO Can Sci Advis Sec Res Doc 2019/059

Brennan CE, Maps F, Gentleman WC, Plourde S and others (2019) How transport shapes copepod distributions in relation to whale feeding habitat: demonstration of a new modelling framework. Prog Oceanogr 171:1-21

Cameletti M, Lindgren F, Simpson D, Rue H (2013) Spatiotemporal modeling of particulate matter concentration through the SPDE approach. AStA Adv Stat Anal 97: 109-131

Chipps SR, Wahl DH (2008) Bioenergetics modeling in the 21st century: reviewing new insights and revisiting old constraints. Trans Am Fish Soc 137:298-313

Christiansen F, Dawson SM, Durban JW, Fearnbach H and others (2020) Population comparison of right whale body condition reveals poor state of the North Atlantic right whale. Mar Ecol Prog Ser 640:1-16

Cooke JG (2020) Eubalaena glacialis (errata version published in 2020). The IUCN Red List of Threatened Species 2020: e.T41712A178589687. https://dx.doi.org/10. 2305/IUCN.UK.2020-2.RLTS.T41712A178589687.en

* Corkeron P, Hamilton P, Bannister J, Best P and others (2018) The recovery of North Atlantic right whales, Eubalaena glacialis, has been constrained by humancaused mortality. R Soc Open Sci 5:180892

Cosandey-Godin A, Krainski ET, Worm B, Mills Flemming J (2015) Applying Bayesian spatiotemporal models to fisheries bycatch in the Canadian Arctic. Can J Fish Aquat Sci 72:186-197

COSEWIC (Committee on the Status of Endangered Wildlife in Canada) (2013) COSEWIC Assessment and status report on the North Atlantic right whale Eubalaena glacialis in Canada. COSEWIC, Ottawa

Costa DP (2012) A bioenergetics approach to developing the PCAD model. In: Popper AN, Hawkins A (eds) The effects of noise on aquatic life. Advances in experimental medicine and biology. Springer, New York, NY, p 423-426

Daoust PY, Couture EL, Wimmer T, Bourque L (2017) Incident report: North Atlantic right whale mortality event in 
the Gulf of St. Lawrence, 2017. Collaborative report produced by: Canadian Wildlife Health Cooperative, Marine Animal Response Society, and Fisheries and Oceans Canada. http://publications.gc.ca/site/eng/9. 845760/publication.html

Davies KT, Ryan A, Taggart CT (2012) Measured and inferred gross energy content in diapausing Calanus spp. in a Scotian Shelf basin. J Plankton Res 34:614-625

* Davies KTA, Brown MW, Hamilton PK, Knowlton AR, Taggart CT, Vanderlaan ASM (2019) Variation in North Atlantic right whale Eubalaena glacialis occurrence in the Bay of Fundy, Canada, over three decades. Endang Species Res 39:159-171

Davis GE, Baumgartner MF, Bonnell JM, Bell J and others (2017) Long-term passive acoustic recordings track the changing distribution of North Atlantic right whales (Eubalaena glacialis) from 2004 to 2014. Sci Rep 7:13460

DFO (Fisheries and Oceans Canada) (2019a) Review of North Atlantic right whale occurrence and risk of entanglements in fishing gear and vessel strikes in Canadian waters. DFO Can Sci Advis Sec Sci Advis Rep 2019/028

DFO (2019b) Oceanographic conditions in the Atlantic zone in 2018. DFO Can Sci Advis Sec Sci Advis Rep 2019/034

DFO (2020) Updated information on the distribution of North Atlantic right whale in Canadian waters. DFO Can Sci Advis Sec Sci Advis Rep 2020/037

* Firestone J, Lyons SB, Wang C, Corbett JJ (2008) Statistical modeling of North Atlantic right whale migration along the mid-Atlantic region of the eastern seaboard of the United States. Biol Conserv 141:221-232

Fish FE (1993) Power output and propulsive efficiency of swimming bottlenose dolphins (Tursiops truncatus). J Exp Biol 185:179-193

Fish FE (1998) Comparative kinematics and hydrodynamics of odontocete cetaceans: morphological and ecological correlates with swimming performance. J Exp Biol 201: 2867-2877

Fish FE (2000) Biomechanics and energetics in aquatic and semiaquatic mammals: platypus to whale. Physiol Biochem Zool 73:683-698

Fish FE, Rohr J (1999) Review of dolphin hydrodynamics and swimming performance. US Navy SPAWAR Syst Cent Tech Rep 1801

Fortune SME, Trites AW, Perryman WL, Moore MJ, Pettis HM, Lynn MS (2012) Growth and rapid early development of North Atlantic right whales (Eubalaena glacialis). J Mammal 93:1342-1354

Fortune SME, Trites AW, Mayo CA, Rosen DAS, Hamilton PK (2013) Energetic requirements of North Atlantic right whales and the implications for species recovery. Mar Ecol Prog Ser 478:253-272

Fortune SME, Ferguson SH, Trites AW, LeBlanc B, LeMay V, Hudson JM, Baumgartner MF (2020a) Seasonal diving and foraging behaviour of Eastern Canada-West Greenland bowhead whales. Mar Ecol Prog Ser 643:197-217

Fortune SME, Moore MJ, Perryman WL, Trites AW (2020b) Body growth of North Atlantic right whales (Eubalaena glacialis) revisited. Mar Mamm Sci 2020:1-15

Fuglstad GA, Simpson D, Lindgren F, Rue H (2019) Constructing priors that penalize the complexity of Gaussian random fields. J Am Stat Assoc 114:445-452

Galbraith PS, Chassé J, Caverhill C, Nicot P, Gilbert D, Lefaivre D, Lafleur C (2019) Physical oceanographic conditions in the Gulf of St. Lawrence during 2018. DFO Can Sci Advis Sec Res Doc 2019/046
Gilbert D, Pettigrew B (1997) Interannual variability (1948-1994) of the CIL core temperature in the Gulf of St. Lawrence. Can J Fish Aquat Sci 54:57-67

* Gneiting T, Raftery AE (2007) Strictly proper scoring rules, prediction, and estimation. J Am Stat Assoc 102:359-378

* Goldbogen JA, Cade DE, Calambokidis J, Friedlaender AS, Potvin J, Segre PS, Werth AJ (2017) How baleen whales feed: the biomechanics of engulfment and filtration. Annu Rev Mar Sci 9:367-386

Goodyear JD (1996) Significance of feeding habitats of North Atlantic right whales based on studies of diel behaviour, diving, food ingestion rates, and prey. $\mathrm{PhD}$ dissertation, Guelph University

Gowan TA, Ortega-Ortiz JG, Hostetler JA, Hamilton PK and others (2019) Temporal and demographic variation in partial migration of the North Atlantic right whale. Sci Rep 9:353

Grieve BD, Hare JA, Saba VS (2017) Projecting the effects of climate change on Calanus finmarchicus distribution within the US northeast continental shelf. Sci Rep 7:6264

* Guisan A, Zimmermann NE (2000) Predictive habitat distribution models in ecology. Ecol Model 135:147-186

*Hall CAS, Stanford JA, Hauer FR (1992) The distribution and abundance of organisms as a consequence of energy balances along multiple environmental gradients. Oikos 65:377-390

*Hamilton PK, Cooper LA (2010) Changes in North Atlantic right whale (Eubalaena glacialis) cow-calf association times and use of the calving ground: 1993-2005. Mar Mamm Sci 26:896-916

*Hamilton PK, Marx MK, Kraus SD (1995) Weaning in North Atlantic right whales. Mar Mamm Sci 11:386-390

Hamner WM, Stone GS, Obst BS (1988) Behavior of southern right whales (Eubalaena australis) feeding on the Antarctic krill (Euphausia superba). Fish Bull 86:143-150

*Harcourt R, van der Hoop J, Kraus S, Carroll EL (2019) Future directions in Eubalaena spp.: comparative research to inform conservation. Front Mar Sci 5:530

*Heide-Jørgensen MP, Laidre KL, Nielsen NH, Hansen RG, Røstad A (2013) Winter and spring diving behavior of bowhead whales relative to prey. Anim Biotelem 1:15

Hertel H (1969) Hydrodynamics of swimming and wave-riding dolphins. In: Andersen HT (ed) The biology of marine mammals. Academic Press, New York, NY, p 31-63

Kaartvedt S (1996) Habitat preference during overwintering and timing of seasonal vertical migration of Calanus finmarchicus. Ophelia 44:145-156

Kaye GWC, Laby TH (1995) Tables of physical \& chemical constants, $16^{\text {th }}$ edn. 2.7.9 Physical properties of seawater. Kaye \& Laby Online. Version 1.0 (2005). https://web. archive.org/web/20190508003610/ http://www.kayelaby. npl.co.uk/general_physics/2_7/2_7_9.html (accessed 22 Apr 2020)

Kearney M, Porter W (2009) Mechanistic niche modelling: combining physiological and spatial data to predict species' ranges. Ecol Lett 12:334-350

Kearney M, Wintle B, Porter W (2010) Correlative and mechanistic models of species distribution provide congruent forecasts under climate change. Conserv Lett 3: 203-213

KKenney RD, Hyman MAM, Owen RE, Scott GP, Winn HE (1986) Estimation of prey densities required by western North Atlantic right whales. Mar Mamm Sci 2:1-13

Kleiber M (1961) The fire of life. An introduction to animal energetics. John Wiley \& Sons, New York, NY 
Kleiber M (1975) Metabolic turnover rate: a physiological meaning of the metabolic rate per unit body weight. J Theor Biol 53:199-204

Kline SJ, Reynolds WC, Schraub FA, Runstadler PW (1967) The structure of turbulent boundary layers. J Fluid Mech 30:741-773

Knowlton AR, Kraus SD, Kenney RD (1994) Reproduction in North Atlantic right whales (Eubalaena glacialis). Can J Zool 72:1297-1305

Krainski ET, Gómez-Rubio V, Bakka H, Lenzi A and others (2018) Advanced spatial modeling with stochastic partial differential equations using $\mathrm{R}$ and INLA. Chapman \& Hall/CRC, Boca Raton, FL

Kraus SD, Rolland R (2007) The urban whale: North Atlantic right whales at the crossroads. Harvard University Press, Cambridge, MA

Krumhansl KA, Head EJH, Pepin P, Plourde S, Record NR, Runge JA, Johnson CL (2018) Environmental drivers of vertical distribution in diapausing Calanus copepods in the Northwest Atlantic. Prog Oceanogr 162:202-222

Krzystan AM, Gowan TA, Kendall WL, Martin J and others (2018) Characterizing residence patterns of North Atlantic right whales in the southeastern USA with a multistate open robust design model. Endang Species Res 36:279-295

Lehoux C, Plourde S, Lesage V (2020) Significance of dominant zooplankton species to the North Atlantic right whale potential foraging habitats in the Gulf of St. Lawrence: a bio-energetic approach. DFO Can Sci Advis Sec Res Doc 2020/033

Lindgren F, Rue H, Lindström J (2011) An explicit link between Gaussian fields and Gaussian Markov random fields: the stochastic partial differential equation approach. J R Stat Soc Ser B Stat Methodol 73:423-498

Lockyer C (1981) Growth and energy budgets of large baleen whales from the southern hemisphere. In: FAO Fisheries Series No. 5, Vol 3: Mammals in the seas. FAO, Rome, p 379-487

Loder JW, Wang Z (2015) Trends and variability of sea surface temperature in the Northwest Atlantic from three historical gridded datasets. Atmos-Ocean 53:510-528

MacNab BK (2002) The physiological ecology of vertebrates - a view from energetics. Cornell University Press, Ithaca, NY

Mayo C, Goldman L (1992) Right whale foraging and the plankton resources in Cape Cod and Massachusetts Bays. In: Hain J (ed) The right whale in the western North Atlantic: a science and management workshop. NOAA Northeast Fisheries Science Center, Woods Hole, MA, p 43-44

Mayo CA, Marx MK (1990) Surface foraging behaviour of the North Atlantic right whale, Eubalaena glacialis, and associated zooplankton characteristics. Can J Zool 68: 2214-2220

Mayo CA, Letcher BH, Scott S (2001) Zooplankton filtering efficiency of the baleen of a North Atlantic right whale, Eubalaena glacialis. J Cetacean Res Manag 3: 245-250

McKinstry CAE, Westgate AJ, Koopman HN (2013) Annual variation in the nutritional value of stage V Calanus finmarchicus: implications for right whales and other copepod predators. Endang Species Res 20:195-204

McQuinn IH, Plourde S, St. Pierre JF, Dion M (2015) Spatial and temporal variations in the abundance, distribution, and aggregation of krill (Thysanoessa raschii and
Meganyctiphanes norvegica) in the lower estuary and Gulf of St. Lawrence. Prog Oceanogr 131:159-176

Meyer-Gutbrod EL, Greene CH (2018) Uncertain recovery of the North Atlantic right whale in a changing ocean. Glob Change Biol 24:455-464

Meyer-Gutbrod EL, Greene CH, Sullivan PJ, Pershing AJ (2015) Climate-associated changes in prey availability drive reproductive dynamics of the North Atlantic right whale population. Mar Ecol Prog Ser 535:243-258

* Miller CA, Best PB, Perryman WL, Baumgartner MF, Moore MJ (2012) Body shape changes associated with reproductive status, nutritive condition and growth in right whales Eubalaena glacialis and E. australis. Mar Ecol Prog Ser 459:135-156

* Miller PJO, Johnson MP, Tyack PL, Terray EA (2004) Swimming gaits, passive drag and buoyancy of diving sperm whales Physeter macrocephalus. J Exp Biol 207: 1953-1967

Miller PJO, Biuw M, Watanabe YY, Thompson D, Fedak MA (2012) Sink fast and swim harder! Round-trip cost-oftransport for buoyant divers. J Exp Biol 215:3622-3630

* Miller P, Narazaki T, Isojunno S, Aoki K, Smout S, Sato K (2016) Body density and diving gas volume of the northern bottlenose whale (Hyperoodon ampullatus). J Exp Biol 219:2458-2468

Moore M, Knowlton A, Kraus S, McLellan W, Bonde R (2005) Morphometry, gross morphology and available histopathology in North Atlantic right whale (Eubalaena glacialis) mortalities (1970 to 2002). J Cetacean Res Manag 6:199-214

* Murison LD, Gaskin DE (1989) The distribution of right whales and zooplankton in the Bay of Fundy, Canada. Can J Zool 67:1411-1420

Nelson TA, Duffus D, Robertson C, Laberee K, Feyrer LJ (2009) Spatial-temporal analysis of marine wildlife. J Coast Res 56 (Spec Issue):1537-1541

* New LF, Moretti DJ, Hooker SK, Costa DP, Simmons SE (2013) Using energetic models to investigate the survival and reproduction of beaked whales (Family Ziphiidae). PLOS ONE 8:e68725

Nousek McGregor AE (2010) The cost of locomotion in North Atlantic right whales Eubalaena glacialis. PhD dissertation, Duke University, Durham, NC

Nousek-McGregor AE, Miller CA, Moore MJ, Nowacek DP (2014) Effects of body condition on buoyancy in endangered North Atlantic right whales. Physiol Biochem Zool 87:160-171

Nowacek DP, Johnson MP, Tyack PL, Shorter KA, McLellan WA, Pabst AD (2001) Buoyant balaenids: the ups and downs of buoyancy in right whales. Proc R Soc B 268: 1811-1816

Oftedal OT (1997) Lactation in whales and dolphins: evidence of divergence between baleen- and toothedspecies. J Mammary Gland Biol Neoplasia 2:205-230

Olsson O, Bolin A (2014) A model for habitat selection and species distribution derived from central place foraging theory. Oecologia 175:537-548

* Pace RM III, Corkeron PJ, Kraus SD (2017) State-space mark-recapture estimates reveal a recent decline in abundance of North Atlantic right whales. Ecol Evol 7: 8730-8741

* Parks SE, Searby A, Célérier A, Johnson MP, Nowacek DP, Tyack PL (2011) Sound production behavior of individual North Atlantic right whales: implications for passive acoustic monitoring. Endang Species Res 15:63-76 
Pepin P, Johnson CL, Harvey M, Casault B and others (2015) A multivariate evaluation of environmental effects on zooplankton community structure in the western North Atlantic. Prog Oceanogr 134:197-220

*Peterson AT, Papeş M, Soberón J (2015) Mechanistic and correlative models of ecological niches. Eur J Ecol 1: 28-38

Pettis HM, Pace RM III, Hamilton PK (2018) North Atlantic Right Whale Consortium 2018 annual report card. Report to the North Atlantic Right Whale Consortium. https:// www.narwc.org/uploads/1/1/6/6/116623219/2018report_ cardfinal.pdf (accessed 22 Apr 2020)

Pettis HM, Pace RM III, Hamilton PK (2020) North Atlantic Right Whale Consortium 2019 annual report card. Report to the North Atlantic Right Whale Consortium. https:// www.narwc.org/uploads/1/1/6/6/116623219/2019report final.pdf (accessed 22 Apr 2020)

* Phillips AB, Haroutunian M, Murphy AJ, Boyd SW, Blake JIR, Griffiths G (2017) Understanding the power requirements of autonomous underwater systems, Part I: an analytical model for optimum swimming speeds and cost of transport. Ocean Eng 133:271-279

Plourde S, Lehoux C, McQuinn IH, Lesage V (2016) Describing krill distribution in the western North Atlantic using statistical habitat models. DFO Can Sci Advis Sec Res Doc 2016/111

* Plourde S, Lehoux C, Johnson CL, Perrin G, Lesage V (2019) North Atlantic right whale (Eubalaena glacialis) and its food: (I) a spatial climatology of Calanus biomass and new potential foraging habitats in Canadian waters. J Plankton Res 41:667-685

* Potvin J, Werth AJ (2017) Oral cavity hydrodynamics and drag production in balaenid whale suspension feeding. PLOS ONE 12:e0175220

R Core Team (2020) R: a language and environment for statistical computing. R Foundation for Statistical Computing, Vienna

Record NR, Runge JA, Pendleton DE, Balch WM and others (2019) Rapid climate-driven circulation changes threaten conservation of endangered North Atlantic right whales. Oceanography 32:162-169

Reygondeau G, Beaugrand G (2011) Future climate-driven shifts in distribution of Calanus finmarchicus. Glob Change Biol 17:756-766

Reynolds O (1883) An experimental investigation of the circumstances which determine whether the motion of water shall be direct or sinuous, and of the law of resistance in parallel channels. Philos Trans R Soc B 174:935-982

Right Whale Consortium (2020) North Atlantic Right Whale Consortium Identification and Sightings Database 08/03/2020. New England Aquarium, Boston, MA

* Runge JA, Castonguay $M$, de Lafontaine Y, Ringuette M, Beaulieu JL (1999) Covariation in climate, zooplankton biomass and mackerel recruitment in the southern Gulf of St Lawrence. Fish Oceanogr 8:139-149

Saba VS, Griffies SM, Anderson WG, Winton M and others (2016) Enhanced warming of the Northwest Atlantic Ocean under climate change. J Geophys Res 121:118-132

Sanderson SL, Wassersug R (1990) Suspension-feeding vertebrates. Sci Am 262:96-102

Saumweber WJ, Durbin EG (2006) Estimating potential diapause duration in Calanus finmarchicus. Deep Sea Res II 53:2597-2617

Sharp SM, McLellan WA, Rotstein DS, Costidis AM and others (2019) Gross and histopathologic diagnoses from
North Atlantic right whale Eubalaena glacialis mortalities between 2003 and 2018. Dis Aquat Org 135:1-31

Sibly RM, Calow P (1986) Physiological ecology of animals. Blackwell Scientific Publications, Oxford

Silber GK, Lettrich MD, Thomas PO, Baker JD and others (2017) Projecting marine mammal distribution in a changing climate. Front Mar Sci 4:413

Simard Y, Roy N, Giard S, Aulanier F (2019) North Atlantic right whale shift to the Gulf of St. Lawrence in 2015, revealed by long-term passive acoustics. Endang Species Res 40:271-284

* Simpson D, Rue H, Riebler A, Martins TG, Sørbye SH (2017) Penalising model component complexity: a principled, practical approach to constructing priors. Stat Sci 32: 1-28

Sorochan KA, Plourde S, Morse R, Pepin P, Runge J, Thompson C, Johnson CL (2019) North Atlantic right whale (Eubalaena glacialis) and its food: (II) interannual variations in biomass of Calanus spp. on western North Atlantic shelves. J Plankton Res 41:687-708

Spiegelhalter DJ, Best NG, Carlin BP, van der Linde A (2002) Bayesian measures of model complexity and fit. J R Stat Soc B 64:583-639

Stephens DW, Krebs JR (1986) Foraging theory. Princeton University Press, Princeton, NJ

* Swaim ZT, Westgate AJ, Koopman HN, Rolland RM, Kraus SD (2009) Metabolism of ingested lipids by North Atlantic right whales. Endang Species Res 6:259-271

Tarling GA, Fielding S (2016) Swarming and behaviour in Antarctic krill. In: Siegel V (ed) Biology and ecology of Antarctic krill. Springer, Cham, p 279-319

*Tomlinson S, Arnall SG, Munn A, Bradshaw SD, Maloney SK, Dixon KW, Didham RK (2014) Applications and implications of ecological energetics. Trends Ecol Evol 29:280-290

Tormosov DD, Mikhaliev YA, Best PB, Zemsky VA, Sekiguchi K, Brownell RL Jr (1998) Soviet catches of southern right whales Eubalaena australis,1951-1971. Biological data and conservation implications. Biol Conserv 86: 185-197

Trassinelli M (2016) Energy cost and optimisation in breathhold diving. J Theor Biol 396:42-52

*van der Hoop J, Moore M, Fahlman A, Bocconcelli A and others (2014) Behavioral impacts of disentanglement of a right whale under sedation and the energetic cost of entanglement. Mar Mamm Sci 30:282-307

* van der Hoop J, Corkeron P, Moore M (2017a) Entanglement is a costly life-history stage in large whales. Ecol Evol 7:92-106

*van der Hoop JM, Nowacek DP, Moore MJ, Triantafyllou MS (2017b) Swimming kinematics and efficiency of entangled North Atlantic right whales. Endang Species Res 32:1-17

*van der Hoop JM, Nousek-McGregor AE, Nowacek DP, Parks SE, Tyack P, Madsen PT (2019) Foraging rate of ram-filtering North Atlantic right whales. Funct Ecol 33: 1290-1306

* van der Vaart E, Johnston ASA, Sibly RM (2016) Predicting how many animals will be where: how to build, calibrate and evaluate individual-based models. Ecol Model 326: 113-123

Vermeulen E, Cammareri A, Holsbeek L (2012) Alteration of southern right whale (Eubalaena australis) behaviour by human-induced disturbance in Bahía San Antonio, Patagonia, Argentina. Aquat Mamm 38:56-64 
Villarino E, Chust G, Licandro P, Butenschön M, Ibaibarriaga L, Larrañaga A, Irigoien X (2015) Modelling the future biogeography of North Atlantic zooplankton communities in response to climate change. Mar Ecol Prog Ser 531:121-142

Villegas-Amtmann S, Schwarz LK, Sumich JL, Costa DP (2015) A bioenergetics model to evaluate demographic consequences of disturbance in marine mammals applied to gray whales. Ecosphere 6:183

Wade PR, De Robertis A, Hough KR, Booth R and others (2011) Rare detections of North Pacific right whales in the Gulf of Alaska, with observations of their potential prey. Endang Species Res 13:99-109

Watanabe S (2010) Asymptotic equivalence of Bayes cross validation and widely applicable information criterion in singular learning theory. J Mach Learn Res 11: 3571-3594

Webb PW (1975) Hydrodynamics and energetics of fish propulsion. Bull Fish Res Board Can 190:1-159

Editorial responsibility: Robert Harcourt, Sydney, New South Wales, Australia

Reviewed by: 3 anonymous referees
Williams TM, Maresh JL (2015) Exercise energetics. In: Castellini MA, Mellish J (eds) Marine mammal physiology: requisites for ocean living. CRC Press, Boca Raton, FL, p 47-68

Williams TM, Davis RW, Fuiman LA, Francis J and others (2000) Sink or swim: strategies for cost-efficient diving by marine mammals. Science 288:133-136

*Wishner KF, Schoenherr JR, Beardsley R, Chen C (1995) Abundance, distribution and population structure of the copepod Calanus finmarchicus in a springtime right whale feeding area in the southwestern Gulf of Maine. Cont Shelf Res 15:475-507

Kakardjian BA, Sheng J, Runge JA, McLaren I, Plourde S, Thompson KR, Gratton Y (2003) Effects of temperature and circulation on the population dynamics of Calanus finmarchicus in the Gulf of St. Lawrence and Scotian Shelf : study with a coupled, three-dimensional hydrodynamic, stage-based life history model. J Geophys Res Oceans 108:8016

Submitted: May 25, 2020

Accepted: November 13, 2020

Proofs received from author(s): February 17, 2021 